\title{
Quarterly Report on the Ferrocyanide Safety Program for the Period Ending March 31, 1996
}

\author{
R. J. Cash \\ J. E. Meacham
}

Date Published

May 1996

Prepared for the U.S. Department of Energy Assistant Secretary for Environmental Management

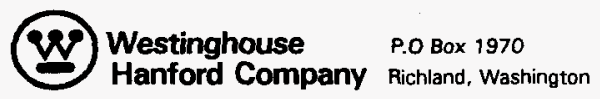

Management and Operations Contractor for the

U.S. Department of Energy under Contract DE-ACO6-87RL10930

Approved for public release; distribution is unlimited 


\section{RELEASE AUTHORIZATION}

Document Number: WHC-EP-0474, Rev. 20

Document Title: Quarterly Report on the Ferrocyanide Safety Program for the Period Ending March 31, 1996

Release Date: $\quad 5 / 8 / 96$

This document was reviewed following the procedures described in WHC-CM-3-4 and is:

APPROVED FOR PUBLIC RELEASE

WHC Information Release Administration Specialist:

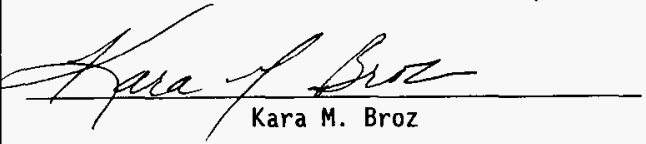

May 8, 1996 
LECAL DISCLAMMER

This report was prepared as an account of work sponsored by an agency of the United Stetes Governmant. Neither the

United States Govermment nor any agency thereof, nor any of their errployees, nor any of their contractors, subcontractors or their employees, makes any warrenty. express or implied, or assumes any lega liability or responsibility for the eccuracy, complateneas, or any third party s use or the results of auch use of env informetion, epperatus, product, or process disclosed, or represents that its use would not infringe privately owned rights. Reference herein to any epecific cormmerciel product, process, or service by trade name, trademark, manufacturer, or otherwige, does not necessarily constitute or imply its endorsement, recommendetion, or favoring by the United States Government or any agency thereof or its contrectors or subcontractors. The views and opinions of authors expresed herein do not necessarily state or reflect those of the United Stetes Government or any agency thereof.

This report has been reproduced from the best available copy. Aveilable in peper copy and microfiche.

Aveilabie to the U.S. Department of Energy and its contractors from

U.S. Department of Energy

Office of Scientific and Tochnical Information (OSTI)

P.O. Box 62

Oak Ridge, TN 37831

(615) 576-840

Available to the public from the U.S. Department of Commerce Nationel Technicel Information Service (NTIS)

5285 Port Royal Roed

Springfield, VA 22161

(703) $487-4650$

Printed in the United Stetee of Americe

DISCLM-1.CHP (8-95) 



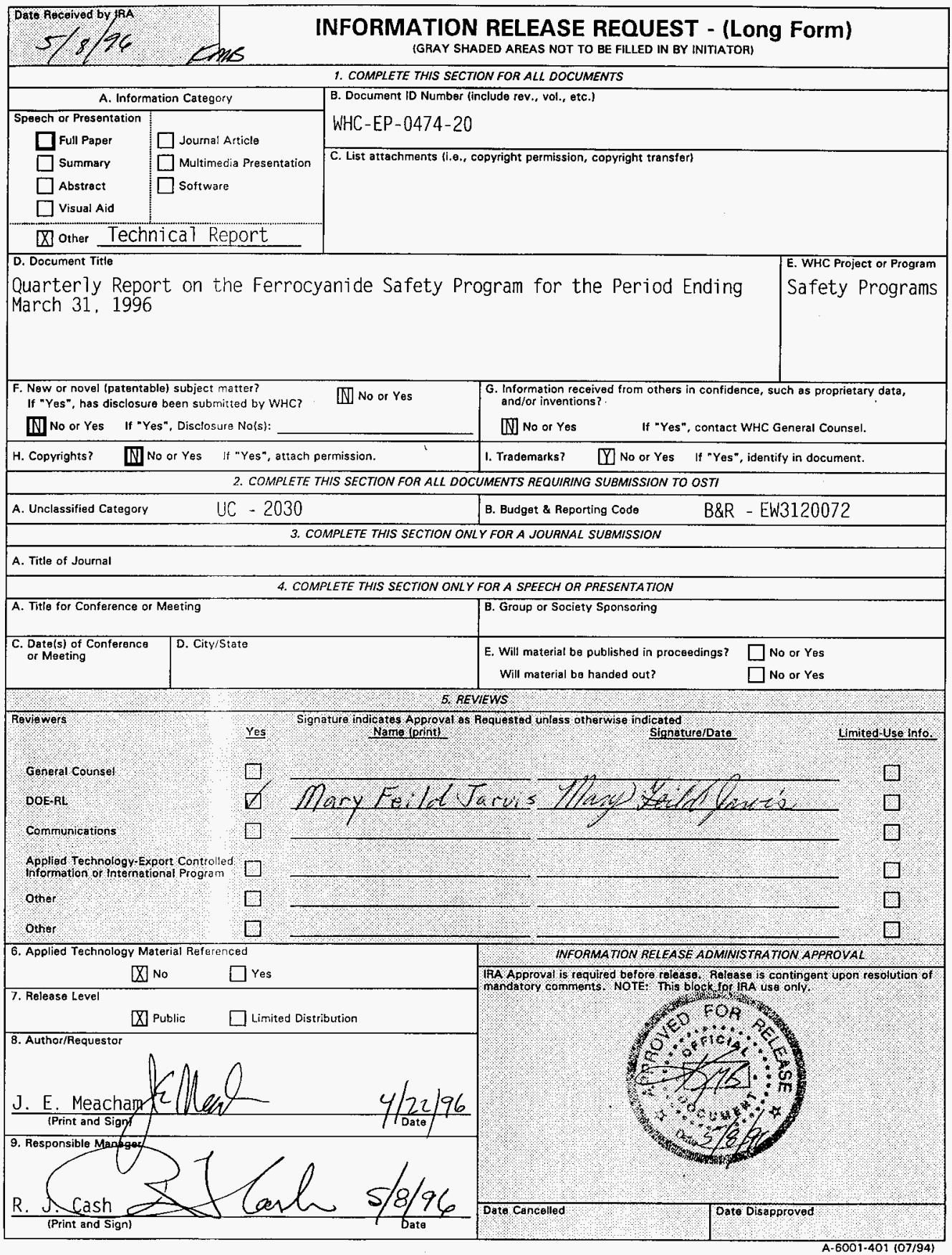


WHC-EP-0474-20

Document ID Number

10. LEGENDS/NOTICES/MARKINGS (Required by WHC-CM-34 or Roviowen, Reviewer indicates applicable markings to be affixed or temoved

Affix Remove Initials

Affix Remove thitals

Applied Technology

Availability osTi

Availabilíty ESTSC

1)

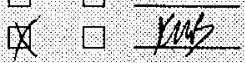

Availability NTIS

\$ా

H.

Business-Sensitive Information

Computer Soltwäe Notice

Copyright License Notice

Export Controlled Information

Legal Disclaimer:

Limited Disclosure

$\square, \square$

$\square, \square$

1 $\square$

0 ए

Xf.

ए.

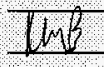

ए।

11 MANDATORY COMMENTS (List only mand atory comments here All other comments shall be mede on the document and returned

to tho suthorl

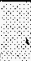

Official Use only

Patent Status

Prodecisional thformation

Programmatic Notics

Proprietary loformation

Purpose and Use

Thesisfoissertation

Trademark Disclaimer

other:

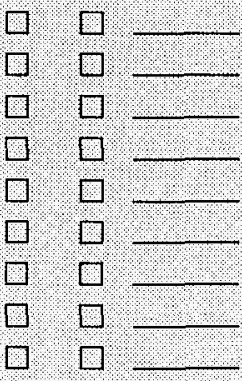

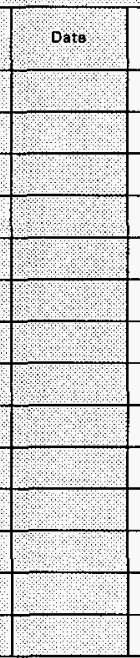

Resolved by Author/Requestor (Print \& Sign) 



\title{
QUARTERLY REPORT ON THE FERROCYANIDE SAFETY PROGRAM FOR THE PERIOD ENDING MARCH 31, 1996
}

\author{
R. J. Cash \\ J. E. Meacham
}

\begin{abstract}
This is the twentieth quarterly report on the progress of activities addressing the

Ferrocyanide Safety Issue associated with Hanford Site high-level radioactive waste tanks.

Progress in the Ferrocyanide Safety Program is reviewed, including work addressing the six parts of Defense Nuclear Facilities Safety Board Recommendation 90-7 (FR 1990). All work activities are described in the revised program plan (DOE 1994b), and this report follows the same format presented there. A summary of the key events occurring this quarter is presented in Section 1.2. More detailed discussions of progress are located in Sections 2.0 through 4.0.
\end{abstract}


This page intentionally left blank. 


\section{CONTENTS}

1.0 INTRODUCTION $\ldots \ldots \ldots \ldots \ldots \ldots \ldots \ldots \ldots \ldots \ldots \ldots \ldots \ldots \ldots \ldots \ldots .1$

1.1 PURPOSE . . . . . . . . . . . . . . . . . .1-1

1.2 QUARTERLY HIGHLIGHTS $\ldots \ldots \ldots \ldots \ldots \ldots \ldots \ldots \ldots \ldots$

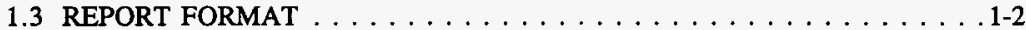

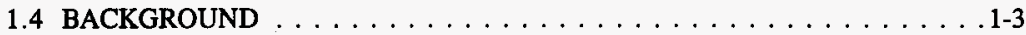

2.0 FERROCYANIDE SAFETY DOCUMENTATION $\ldots \ldots \ldots \ldots \ldots \ldots$

3.0 ACTIONS TO COMPLETE DNFSB RECOMMENDATION $90-7 \ldots \ldots \ldots$. . . . . .

3.1 ENHANCED TEMPERATURE MEASUREMENT $\ldots \ldots \ldots \ldots \ldots$. $\ldots \ldots$

3.1.1 Instrument Trees . . . . . . . . . . . . . . . . . . 3-1

3.1.2 Upgrades to Existing Temperature Monitoring Instrumentation . . . . 3-2

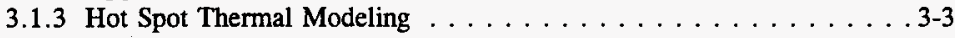

3.1.4 Infrared Scanning System . . . . . . . . . . . . . . .3-3

3.1.5 Cooling System Requirements . . . . . . . . . . . . . . . 3-4

3.2 CONTINUOUS TEMPERATURE MONITORING $\ldots \ldots \ldots \ldots \ldots \ldots$. $\ldots \ldots$

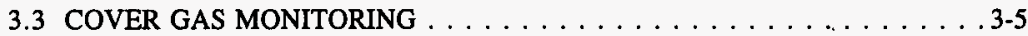

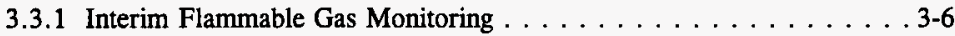

3.3.2 Continuous Gas Monitoring $\ldots \ldots \ldots \ldots \ldots \ldots \ldots \ldots \ldots$

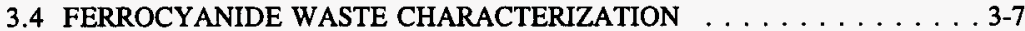

3.4.1 Ferrocyanide Tank Waste Sampling and Analyses . . . . . . . 3-8

3.4.2 Estimation of Water Content . . . . . . . . . . . . 3-14

3.4.3 Moisture Retention Properties of Ferrocyanide Sludge and Saltcake Simulants . . . . . . . . . . . . . 3-17

3.5 CHEMICAL REACTION STUDIES . . . . . . . . . . . . . 3-18

3.5.1 Chemical Reaction Studies at Pacific Northwest National Laboratory 3-18

3.5.2 Preparation and Characterization of Ferrocyanide Simulants . . . . 3-23

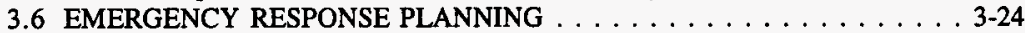

4.0 IMPLEMENTATION OF THE WYDEN AMENDMENT $\ldots \ldots \ldots \ldots \ldots \ldots$ 4-1

4.1 THE WATCH LIST . . . . . . . . . . . . . . . . . . . 4-1

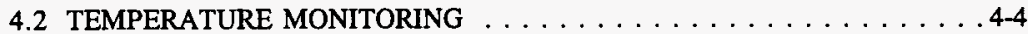

4.3 PRESSURE MONITORING $\ldots \ldots \ldots \ldots \ldots \ldots \ldots \ldots \ldots .4 .4 \ldots \ldots$

5.0 PROGRAM SCHEDULES AND MILESTONES $\ldots \ldots \ldots \ldots \ldots \ldots$ 5-1

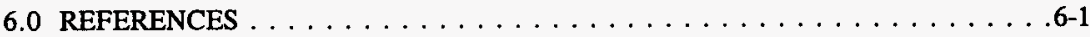

APPENDIX

A FERROCYANIDE TANK INFORMATION SUMMARY $\ldots \ldots \ldots \ldots \ldots$ A-1 


\section{LIST OF FIGURES}

3-1 Radiolysis of Formate Ion at $1 \times 10^{5} \mathrm{Rad} / \mathrm{h}$ in $2 \mathrm{M} \mathrm{NaOH}$ at Ambient

Temperature . . . . . . . . . . . . . . . . . . . 3-20

3-2 Ammonia Production During Hydrolysis of $\mathrm{Ni}(\mathrm{CN})_{4}^{-2} \ldots \ldots \ldots \ldots .3 .20$

3-3 The Effect of $\mathrm{NO}_{3}^{-} / \mathrm{NO}_{2}^{-}$on Ammonia Production During Hydrolysis of $\mathrm{Ni}(\mathrm{CN})_{4}^{-2} \quad 3-21$

3-4 $\mathrm{N}_{2}$ and $\mathrm{H}_{2}$ Generation and $\mathrm{NH}_{3}$ Destruction as a Function of Dose Rate . . . . 3-21

3-5 Reproducibility of Ammonia Production in Aging Experiments . . . . . . . 3-22

5-1 Ferrocyanide Waste Tank Safety Schedule . . . . . . . . . . . 5-2

\section{LIST OF TABLES}

3-1 Tank 241-BY-104 Waste Sample (Averaged) Data for Core $116 \ldots \ldots$. . . . . .

3-2 Tank 241-BY-104 Waste Sample (Averaged) Data for Core $117 \ldots$. . . . . . 3-11

3-3 Summary of Rate Constants for Aging of $\mathrm{Ni}(\mathrm{CN})_{4}^{-2}$ and In-Farm Waste Simulant . 3-19

A-1 Summary of Contents and Status of Ferrocyanide Tanks $\ldots \ldots \ldots \ldots \ldots$ A-3

A-2 Ferrocyanide Tank Vapor Sampling Summary $\ldots \ldots \ldots \ldots \ldots \ldots$ A-5 


\section{LIST OF TERMS}

$\mathrm{cal} / \mathrm{g}$

DNFSB

DOE

DOE-RL

DQO

EA

EMI

FAI

FY

g-mole

GAO

IR

ISB

$\mathrm{J} / \mathrm{g}$

$\mathrm{kW}$

LOW

NASA

NIR

PNNL

ppmv

ppm

$\mathrm{Rad} / \mathrm{h}$

SA

SEM

SST

TC

TCR

TMACS

TOC

USQ

wt\% calories per gram

Defense Nuclear Facilities Safety Board

U.S. Department of Energy

U.S. Department of Energy, Richland Operations Office

data quality objectives

environmental assessment

electromagnetic induction

Fauske and Associates, Inc.

fiscal year

gram-mole

U.S. General Accounting Office

infrared

interim safety basis

Joules per gram

kilowatt

liquid observation well

National Aeronautics and Space Administration

near infrared

Pacific Northwest National Laboratory

parts per million by volume

parts per million by weight

Rad per hour

safety assessment

scanning electron microscope/microscopy

single-shell tank

thermocouple

tank characterization report

Tank Monitor and Control System

total organic carbon

unreviewed safety question

weight percent 
This page intentionally left blank. 


\subsection{INTRODUCTION}

\subsection{PURPOSE}

This quarterly report provides a status of activities underway on the Ferrocyanide Safety Issue at the Hanford Site, including actions in response to Defense Nuclear Facilities Safety Board (DNFSB) Recommendation 90-7 (FR 1990). In March 1991, a DNFSB implementation plan (Cash 1991) responding to the six parts of Recommendation 90-7 was prepared and sent to the DNFSB. A ferrocyanide safety program plan addressing the total Ferrocyanide Safety Program, including the six parts of DNFSB Recommendation 90-7, was released in October 1994 (DOE 1994b). Activities in the program plan are underway or are completed, and the status of each is described in Sections 2.0 and 3.0 of this report.

\subsection{QUARTERLY HIGHLIGHTS}

- The technical basis safety document, WHC-SD-WM-SARR-038, Rev. 0, for deleting four C-Farm ferrocyanide tanks from the Wyden Amendment Watch List (Public Law 101-510, 1990) was submitted to DOE on January 31, 1996 as scheduled (Bacon 1996a, Grigsby et al. 1996a). This document is presently being updated as Revision 1 to add the technical basis for deleting the remaining 14 ferrocyanide tanks from the Watch List. The document will be forwarded to DOE for action next quarter. Approval to delete all 18 ferrocyanide tanks will resolve the Ferrocyanide Safety Issue.

- Analytical results from two full-depth core samples obtained from ferrocyanide tank 241-BY-104 were made available this quarter. As expected the total cyanide ( $\mathrm{CN}$ ) results were very low, in the low parts per million by weight (ppm) range. Although some energetics were observed in the differential scanning calorimeter determinations, the values could be accounted for in terms of the measured total organic carbon (TOC) values. Corresponding nickel values for these samples will be available next quarter.

- The tank characterization report (TCR) for tank 241-BY-108 was issued in February. Although several quarter segments from this tank exhibited the notification limit of 480 Joules per gram (J/g) for energetics, the total cyanide values in these samples were low, more than a factor of ten less than predicted from process records and ferrocyanide waste simulants. These data were reported last quarter (Cash and Meacham 1996). 
- Flammable gas Watch List tank controls imposed on all 177 high-level waste tanks in November 1995 have prevented rotary mode core sampling of selected ferrocyanide tanks. Ferrocyanide tanks 241-BY-103 and 241-TY-103 were planned for last quarter and are now scheduled for the last quarter of fiscal year (FY) 1966. A safety assessment (SA) is being prepared to address the safety requirements and controls required for rotary mode core sampling. Approval of the SA by the U.S. Department of Energy (DOE) is expected next quarter.

- Because rotary mode core sampling has been deferred, the scheduled ferrocyanide TCR milestones have also been delayed. Five ferrocyanide TCRs were to have been issued this quarter. However, only two of the five scheduled tanks have been sampled and the final analytical reports for these two tanks will not be available until next quarter. Although two of these TCRs are scheduled for FY 1996, the milestone to issue five TCR reports will not be completed until FY 1997.

- Funding for the Mössbauer spectroscopy and the scanning electron microscope (SEM) tasks were terminated this quarter when a financial Change Request was approved by Westinghouse Hanford Company and the U.S. Department of Energy, Richland Operations Office (DOE-RL). The tasks were deleted from the scope of work for the Ferrocyanide Safety Program because completion of these efforts is not required to resolve the Ferrocyanide Safety Issue planned by the end of FY 1966. Both tasks are continuing at Westinghouse Hanford Company under a separate source of funding.

- Ferrocyanide aging tests have shown that radiolysis of formate ion results in the generation of carbonate, an ion more stable than formate. The tetracyanonickelate ion, $\mathrm{Ni}(\mathrm{CN})_{4}^{-2}$, was previously shown to be an intermediate species in the aging of ferrocyanide, and nitrogen and hydrogen are also formed from the destruction of ammonia under exposure to radiation. Radiolysis of $\mathrm{Ni}(\mathrm{CN})_{4}^{-2}$ was found to be three times faster when nitrate/nitrite ions are present. Several duplicate experiments are also underway to check on the reproducibility of data reported previously.

- A Westinghouse Hanford Company report (WHC-SD-WM-ER-543, Rev. 0) prepared by Fauske and Associates, Inc. (FAI) was issued this quarter (Fauske 1996). The report concludes that the condensed phase of the waste is substantially more stable and more difficult to ignite than originally thought.

\subsection{REPORT FORMAT}

Progress reports for activities under each of the six parts of DNFSB Recommendation 90-7 are arranged in the same order as the program plan (DOE 1994b). The arrangement also follows the same order provided in Recommendation 90-7. To report on progress, each part of the recommendation is repeated in italics, followed by paragraphs explaining the scope of work on each part or subpart of the recommendation. Subheadings for each task activity report the following: 
- Progress During Reporting Period

- Planned Work for Subsequent Months

- Problem Areas and Action Taken

- Milestone Status.

\subsection{BACKGROUND}

Since the mid-1940s, various high-level radioactive wastes from defense operations have accumulated at the Hanford Site in underground storage tanks. During the 1950s, additional tank storage space was required to support the defense mission. To obtain this additional storage volume within a short time period, and to minimize the need for constructing additional storage tanks, Hanford Site scientists developed a process to scavenge ${ }^{137} \mathrm{Cs}$ and ${ }^{90} \mathrm{Sr}$ from tank waste liquids. In implementing this process, approximately 140 metric tons (154 tons) of ferrocyanide were added to waste that was later routed to a number of Hanford Site single-shell tanks (SSTs) (Sloat 1954, 1955).

In the presence of oxidizing material such as sodium nitrate and/or nitrite, ferrocyanide can be made to react exothermically by heating it to high temperatures or by applying an electrical spark of sufficient energy (Cady 1993). However, fuel, oxidizers, and temperature are all important parameters. If fuel, oxidizers, or high temperatures (initiators) are not present in sufficient amounts, then a runaway or propagating reaction cannot occur.

In 1990, little was known about the potential hazards of a ferrocyanide-nitrate/nitrite reaction in Hanford Site SSTs. Because the safety envelope was not adequately defined by existing analyses, an inadequacy existed in the authorization basis ${ }^{2}$. That is, the existing safety analysis report (Smith 1986) and subsequent analyses such as the 1987 environmental impact statement (DOE 1987) did not adequately define the conditions necessary to preclude propagating reactions in the ferrocyanide waste; therefore, an unreviewed safety question (USQ) was declared (Deaton 1990).

Based on the knowledge gained from simulant studies, theoretical analyses, and analyses of actual waste samples, safety criteria were defined for the ferrocyanide waste (Postma et al. 1994a). These criteria were reviewed and accepted by outside reviewers and reviewers within DOE. The USQ was closed on March 1, 1994 by the DOE Assistant Secretary for Environmental Restoration and Waste Management (Sheridan 1994a).

${ }^{1}$ The U.S. Department of Energy (DOE) authorization basis characterizes the facility design basis and operational requirements for each nuclear facility. The authorization basis is described in documents such as facility safety analysis reports and other safety analyses, hazard classification documents, technical safety requirements, DOE-issued safety evaluation reports, and facility-specific commitments, such as safety assessments for specific tank operations and the Interim Safety Basis (Wagoner 1993). 
In September 1990, an ad hoc task force report (Kress et al. 1990) recommended that studies be performed to provide information on (1) the potential for a ferrocyanide-nitrate/nitrite explosion; (2) the conditions necessary in the tanks to initiate an explosion; and (3) the potential consequences of such an occurrence. The U.S. General Accounting Office (GAO) advised the Secretary of Energy to implement these recommendations (Peach 1990). A closeout report addressing all three GAO recommendations was submitted to DOE in June 1994 (Payne 1994a). The closeout report summarizes the progress made on determining the potential for ferrocyanide reactions in Hanford Site ferrocyanide tanks, and the conditions necessary to sustain an exothermic ferrocyanide reaction.

In March 1989 (Nguyen 1989), based on process knowledge, process records, transfer records, and $\log$ books, 22 Hanford Site tanks were identified as potentially containing 1,000 gram-moles (g-moles) ${ }^{2}(211 \mathrm{~kg}$ [465 lb]) or more of ferrocyanide [as the $\mathrm{Fe}(\mathrm{CN})_{6}^{4}$ anion]. Two additional ferrocyanide tanks were identified in January 1991 (Borsheim and Cash 1991), increasing the number of ferrocyanide tanks to 24: To avert possible injury to personnel and damage to the facility or environment, strict controls were identified for these and other safety issue tanks in Operating Specifications for Watch List Tanks (WHC 1990). Tanks identified by this document (see WHC [1996] for the latest revision) have been commonly referred to as Watch List tanks. In October 1990 (Deaton 1990), the Ferrocyanide Safety Issue was declared a USQ (see Section 2.1) because the safety envelope for these tanks was no longer considered to be bounded by the existing safety analysis report (Smith 1986).

In November 1990, the Wyden Amendment (Public Law 101-510, Section 3137 [1990]) was enacted. This law required the identification of Hanford Site tanks that may have a serious potential for release of high-level waste (see Section 4.0). In February 1991 (Harmon 1991), the 24 ferrocyanide tanks were among the tanks identified, and were included in the subsequent July 1991 report to Congress (Watkins 1991) that responded to the Wyden Amendment. However, re-examination of the historical records (Borsheim and Simpson 1991) indicated that six of the 24 tanks did not contain the requisite 1,000 g-moles of ferrocyanide. Therefore, these six tanks should not have been included on the Watch List nor identified in the response to the Wyden Amendment. The six tanks were subsequently removed from the Watch List (Anttonen 1993, Sheridan 1994b).

${ }^{2}$ The 1,000 g-moles criterion has since been replaced with a 115 calories per gram (cal/g) fuel concentration criterion. See Section 4.1 for discussion. 


\subsection{FERROCYANIDE SAFETY DOCUMENTATION}

The USQ process depends on an authorization basis that describes those aspects of the facility design basis and operational requirements relied on by DOE to authorize operation. The authorization basis is described in documents such as facility safety analysis reports and other safety analyses, hazard classification documents, technical safety requirements, DOE-issued safety evaluation reports, and facility-specific commitments, such as SAs, the interim safety basis (ISB), and the Final Safety Analysis Report (FSAR) scheduled for completion in December 1996. The potential hazards of a ferrocyanide-nitrate/nitrite reaction were discovered to represent an inadequacy in the authorization basis (Smith 1986). The Ferrocyanide USQ was closed on March 1, 1994 by the DOE Assistant Secretary for Environmental Restoration and Waste Management (Sheridan 1994a). Progress on the remaining safety documentation for resolving the Ferrocyanide Safety Issue is reviewed in this section.

Safety and Environmental Assessments. SAs are documents prepared to provide the technical basis to assess the safety of a proposed activity and to provide proper controls to maintain safety. The SA and the accompanying environmental assessment (EA) for that operation provide the basis for DOE authorization of the proposed activities. SAs have been approved for headspace sampling of all ferrocyanide tanks, waste surface sampling, push-mode and rotary-mode core sampling, thermocouple (TC)/instrument tree installation in sound and assumed leaker tanks, and removal of pumpable liquid (interim stabilization). A generic EA covering all proposed operations in the tank farms was approved and a Finding of No Significant Impact issued by DOE (Gerton 1994). Approval of the generic EA provides adequate National Environmental Policy Act coverage for the planned Ferrocyanide Safety Program activities.

The authorization basis for intrusive tank operations was combined into one document, the ISB, which was approved in November 1993 (Wagoner 1993). Safety documentation concerning the ferrocyanide hazard was updated to reflect the approved ferrocyanide safety criteria and closure of the Ferrocyanide USQ. This information is also being incorporated into the FSAR that will replace the ISB when approved by DOE.

Hazard Assessment. A report assessing the ferrocyanide waste tank hazards was issued in July 1992 (Grigsby et al. 1992). The report reviewed the understanding of the ferrocyanide hazard at that time, and presented an integrated evaluation and interpretation of historical data and then-available information. Additional data are now available on the potential for exothermic ferrocyanide reactions in Hanford Site SSTs.

The ferrocyanide hazard assessment document, WHC-SD-WM-SARR-038, Revision 0, Assessment of the Potential for Ferrocyanide Propagating Reaction Accidents, was transmitted to DOE-RL on January 31,1996; minor comments were incorporated into the document as Revision 0A and the document was retransmitted to DOE-RL on March 19, 1996 (Grigsby et al. 1996b). Revision OA was subsequently forwarded to the DNFSB by 
DOE-RL on April 10, 1996 (Trine 1996). The document provides the technical basis for removal of the four C-Farm ferrocyanide tanks from the Watch List. Work on Revision 1 of the document started this quarter, addressing all 18 ferrocyanide tanks. This report is due to DOE by August 30, 1996, with an enhanced date of July 3, 1996. This document will provide the technical basis for removal of all 18 ferrocyanide tanks from the Watch List. Technical information from all Ferrocyanide Safety Program tasks will be compiled into this document, and the ISB (or FSAR) will be amended accordingly.

Ferrocyanide Program Plan. A ferrocyanide program plan was submitted to the DNFSB in December 1994 (O'Leary 1994). The program plan outlines activities planned to address DNFSB Recommendation 90-7, to meet the Wyden Amendment requirements (Public Law 101-510, Section 3137 [1990]), and to remove the remaining ferrocyanide tanks from the Watch List. All ferrocyanide program activities are scheduled to be completed by the end of FY 1997. However, an increased understanding of radiolytic and chemical degradation (aging) of ferrocyanide indicates that little ferrocyanide remains, and core sampling of all the tanks may not be required. Core sampling and analyses of only those tanks that bound aging (i.e., tanks with conditions least conducive to aging) could result in resolution of the Ferrocyanide Safety Issue much earlier and at a substantially reduced cost. As more core sample data become available, the need to sample all the ferrocyanide tanks will be reexamined.

\section{- Milestone Status}

- January 31, 1996. Westinghouse Hanford Company issues documentation supporting safety issue resolution for the four C-Farm tanks and recommends their removal from the Wyden Amendment Watch List (Public Law 101-510, 1990). Document WHC-SD-WM-SARR-038, Revision 0, Assessment of the Potential for Ferrocyanide Propagating Reaction Accidents, was transmitted to DOE-RL as scheduled (Bacon 1996a, Grigsby et al. 1996a). All four C-Farm tanks were sampled earlier and data interpretation reports have been completed for these tanks.

The report was revised to incorporate informal comments received from DOE-RL and reissued with the same title as WHC-SD-WM-SARR-038, Revision 0A, (Grigsby et al. 1996b). The revised report was transmitted to DOE-RL with a letter requesting that the four C-Farm tanks be removed from the Watch List on March 19, 1996 (Bacon 1996b). The report was subsequently forwarded to the DNFSB Staff on April 10, 1996 (Trine 1996).

- July 31, 1996. Westinghouse Hanford Company receives DOE approval to remove the four C-Farm ferrocyanide tanks from the Watch List. 
- July 31, 1996. Westinghouse Hanford Company prepares and submits the final ferrocyanide hazard assessment for DOE approval providing the technical basis for removing all 18 ferrocyanide tanks from the Watch List and resolution of the Ferrocyanide Safety Issue. The official due date for this milestone is August 30, 1996, with an enhanced date of July 3, 1996.

- September 30, 1997. Westinghouse Hanford Company receives DOE approval for Ferrocyanide Safety Issue resolution. It is anticipated that DOE will approve this request by September 30, 1996, based on early submittal of the final hazard assessment. 
WHC-EP-0474-20

This page intentionally left blank. 


\subsection{ACTIONS TO COMPLETE DNFSB RECOMMENDATION 90-7}

This section follows the format of the program plan (DOE 1994b) and describes all work associated with the Ferrocyanide Safety Program. Where applicable, each task activity is described relative to the DNFSB Recommendation (90-7.1 through 90-7.6). The specific part of the recommendation is given, followed by a summary of activities underway to respond to that part of Recommendation 90-7 (if not already closed out).

\subsection{ENHANCED TEMPERATURE MEASUREMENT}

"Immediate steps should be taken to add instrumentation as necessary to the SSTs containing ferrocyanide that will establish whether hot spots exist or may develop in the future in the stored waste. The instrumentation should include, as a minimum, additional thermocouple trees. Trees should be introduced at several radial locations in all tanks containing substantial amounts of ferrocyanide, to measure the temperature as a function of elevation at these radii. The use of infrared techniques to survey the surface of waste in tanks should continue to be investigated as a priority matter, and on the assumption that this method will be found valuable, monitors based on it should be installed now in the ferrocyanide bearing tanks."

\subsubsection{Instrument Trees}

All new instrument trees planned for the ferrocyanide tanks have been installed; this action was completed in August 1995. Originally, several new temperature measurement instruments were to be installed into each tank. This plan was modified to ensure that at least one instrument tree with replaceable temperature-sensing elements was in each ferrocyanide tank. The new trees have at least two operational temperature-sensing elements in the waste to ensure a true temperature measurement, and one or more elements in the headspace. The number of temperature sensing elements in the new trees is typically six but some tanks with larger inventories of waste contain up to eight elements.

The decision to put only one new tree into each tank was based on the following: (1) many of the TC elements in the existing trees were returned to service in FY 1992, and measured temperatures are as expected (Bussell 1992); (2) thermal modeling (McLaren 1994a, 1994b) and an enhanced understanding of waste properties show that formation of hot spots in ferrocyanide tanks is not credible (Dickinson et al. 1993, Epstein et al. 1994); and (3) new calculations of tank heat content based on tank temperatures show lower values than previous estimates (Crowe et al. 1993, McLaren 1994a, 1994b).

There are two instrument trees in all but three ferrocyanide tanks (241-BY-106, -BY-111, and -BY-112). The instrument tree in tank 241-BY-106 already had replaceable temperature sensing elements, and tanks 241-BY-111 and -BY-112 previously had no operable instrument 
trees. The instrument trees in the ferrocyanide tanks are monitored continuously by the Tank Monitor and Control System (TMACS). The older instrument trees are expected eventually to fail in a manner such that they cannot be repaired, and they will not be replaced. The highest temperatures recorded in each of the tanks for the quarter ending March 31, 1996 are listed in Appendix A, Table A-1.

- Progress During Reporting Period. The last of 16 new instrument trees were installed in the 18 ferrocyanide tanks in August 1995. A total of 33 working instrument trees and a TC element in each liquid observation well (LOW) of tanks 241-BY-111 and -BY-112 are continuously monitored by TMACS. All work is complete for this task and DNFSB Recommendation 90-7.1 is closed.

- Planned Work for Subsequent Months. None.

- Problem Areas and Action Taken. None.

- Milestone Status. None.

\subsubsection{Upgrades to Existing Temperature Monitoring Instrumentation}

This task determined the operability and accuracy of previously installed TC elements in the original 24 ferrocyanide Watch List tanks. The original and newly installed instrument trees provide temperature measurements for each of the ferrocyanide tanks.

Field measurements were taken in 1991 on each TC element in the then-existing trees to determine the resistance and voltage across the junction and across each lead to ground. The exact condition of each TC element was determined by resistance and voltage measurements (Bussell 1992). This work was completed in FY 1991 with a total of 265 TC elements evaluated. Work in FY 1992 focused on repair and recovery of 92 TC elements that were found to be failed or marginal in performance. This task was completed in FY 1992 for the Ferrocyanide Safety Program.

- Progress During Reporting Period. No progress was required or planned for the Ferrocyanide Safety Program.

- Planned Work for Subsequent Months. None.

- Problem Areas and Actions Taken. None.

- Milestone Status. This task is complete for the Ferrocyanide Safety Program. 


\subsubsection{Hot Spot Thermal Modeling}

Radioactive materials decaying in Hanford Site waste tanks generate heat. An early concern, raised when the ferrocyanide tanks first became a safety issue, was whether an exothermic excursion and local propagation could occur within the ferrocyanide waste if a sufficient concentration of ferrocyanide and a high enough temperature were present. This task examined the available temperature data from the ferrocyanide tanks in order to determine the heat load and temperatures as a function of depth and radial location. Sensitivity and parametric analyses were included to determine the magnitude of a hot spot that would have to exist for the waste to reach propagation temperatures.

Heat load analyses and thermal characteristics were completed for all ferrocyanide tanks in FY 1994 (McLaren 1994a, 1994b). The maximum heat load of any ferrocyanide tank, assuming worst-case conditions for soil moisture and thermal conductivity, was below 4.2 kilowatts (kW). Nominal heat loads calculated by McLaren (1994a, 1994b) compared very favorably with those calculated independently in 1993 (Crowe et al. 1993). A dryout analysis was also completed and released in FY 1994 (Epstein et al. 1994). The report concluded that ferrocyanide sludge could not dry sufficiently to be chemically reactive during interim storage, either globally or locally. Dryout mechanisms evaluated included global evaporation, removal of liquid by leakage or pumping, boiling as a result of hot spots, and enhanced surface evaporation from hot spots. All activities were completed for this task in FY 1994.

- Progress During the Reporting Period. None.

- Planned Work for Subsequent Months. None.

- Problem Areas and Action Taken. None.

- Milestone Status. This task is complete.

\subsubsection{Infrared Scanning System}

Infrared (IR) scanning systems are commercially available from numerous vendors. These systems are sensitive to changes of $\pm 0.3{ }^{\circ} \mathrm{C}$ or less under ideal conditions and offer promise for mapping surface temperature profiles in the ferrocyanide tanks. Thermal modeling performed on ferrocyanide tank 241-BY-104 (McLaren 1993) suggested that if hot spots with temperatures of concern are possible, surface temperature differences might be great enough to be detected by IR mapping.

A position paper on the credibility of hot spots and the need for further IR scanning was issued in April 1993 (Dickinson et al. 1993). Further analyses have been performed to assess potential dryout of the ferrocyanide waste (Epstein et al. 1994). These reports examined potential mechanisms for forming hot spots. Analyses indicate that hot spots are 
not credible in ferrocyanide tanks. Based on these analyses, Westinghouse Hanford Company recommended that no further planning be pursued for IR scans for the purpose of detecting hot spots; work on this Ferrocyanide Safety Program task was stopped at the end of FY 1993.

- Progress During the Reporting Period. None.

- Planned Work for Subsequent Months. None.

- Problem Areas and Action Taken. None.

- Milestone Status. This task is complete.

\subsubsection{Cooling System Requirements}

The program plan for resolution of the Ferrocyanide Safety Issue (DOE 1994b) provided actions that would be taken to cool the ferrocyanide tanks if it were found that such cooling was necessary. Several tentative milestones, identified below, were established for use if a cooling system(s) were to be required. The concern at the time was that increasing temperatures could lead to loss of moisture within the ferrocyanide waste matrix. Immediate emergency actions that would be taken if increased temperatures were to occur are described in the Action Plan for Response to Abnormal Conditions in Hanford Site Radioactive Waste Tanks Containing Ferrocyanide (Fowler 1994). Types of cooling systems might include, but are not limited to, the following: (1) forced ventilation of the tank, using an existing or new exhauster system; (2) air conditioning the air to the tank; (3) adding humid air or mist; and (4) adding water to the tank.

Based on the historical database, anatytical data on samples from ferrocyanide tanks, and resuits from the Pacific Northwest National Laboratory (PNNL) aging test activity, none of the 18 ferrocyanide tanks contain a high enough concentration of ferrocyanide for a propagating reaction to occur. Because dryout of the waste under the present storage conditions (Epstein et al. 1994) is not credible, a special cooling system for the ferrocyanide tanks is not considered necessary. No further work on this task is planned.

- Progress During the Reporting Period. None.

- Planned Work for Subsequent Months. None.

- Problem Areas and Action Taken. None.

- Milestones Status. None. 


\subsection{CONTINUOUS TEMPERATURE MONITORING}

"The temperature sensors referred to above [Recommendation 90-7.1] should have continuous recorded readouts and alarms that would signal at a permanently manned location any abnormally high temperatures and any failed temperature instrumentation."

This task provided continuous monitoring of presently installed (and operable) temperature-sensing elements for the ferrocyanide tanks. New instrument trees were connected to TMACS shortly after they were installed into each tank, resulting in continuous temperature monitoring in the ferrocyanide tanks. All data are collected automatically at the continuously manned Computer Automated Surveillance System Operator Control Station. The monitoring system is independent of the Computer Automated Surveillance System and displays data to an operator on request. Trend data on selected points are available for display in numeric or graphic form.

The TMACS system, which became operational in September 1991, provides alarms for a change in the value of any temperature point. Alarms, if they occur, trigger an audible annunciator and are logged immediately to hard copy. An alarm summary display provides a list of the most recent alarms in order of occurrence. Each alarm can be identified by point and time of occurrence. Operator acknowledgement of the alarm will silence the audible annunciator. Signal conditioning and multiplexing are performed locally at each tank, eliminating the need to transmit low-level signals to the tank farm boundary and reducing cable runs. Electronic noise, extension wire corrosion, and thermal gradients are also reduced.

- Progress During Reporting Period. Temperatures measured by 33 instrument trees and two TC elements in LOWs in the ferrocyanide tanks are being monitored continuously by TMACS. This work was completed in August 1995, and DNFSB Recommendation 90-7.2 is closed. The highest temperatures recorded in each of the tanks for the quarter ending March 31, 1996 are listed in Appendix A, Table A-1.

- Planned Work For Subsequent Months. None.

- Problem Areas and Action Taken. None.

- Milestone Status. None.

\subsection{COVER GAS MONITORING}

"Instrumentation should also be installed to monitor the composition of cover gas in the tanks, to establish if flammable gas is present." 


\subsubsection{Interim Flammable Gas Monitoring}

Flammable and toxic gas monitoring and analyses in the ferrocyanide tanks and other Hanford Site waste tanks are continuing. This effort was transferred to the Tank Vapor Monitoring Program, which is coordinating interim gas monitoring of the ferrocyanide tanks and tanks involved with the tank vapor program. Tank headspaces are measured for flammability using a commercial combustible gas monitor (calibrated with pentane gas), and are monitored for potential toxic gases using an organic vapor monitor and Dräger $^{3}$ tubes. Headspace characterization of all the Hanford Site high-level waste tanks is continuing using sorbent tubes placed on the end of tubes lowered into the headspace and SUMMA ${ }^{4}$ canisters that collect gas samples topside. The initial headspace sampling was done in several tank locations (i.e., from two widely separated risers) and at three elevations in the headspace. Reviews of sampling data and modeling (Wood 1992, Claybrook and Wood 1994, Postma et al. 1994b) indicate that the headspace is well mixed and that sampling from one riser at one elevation is adequate.

- Progress During Reporting Period. Headspace sampling of all 18 ferrocyanide tanks as required for this task was completed in May 1995. Table A-2 in Appendix A summarizes the results. Headspace sampling of the ferrocyanide tanks will continue on a periodic basis as part of the Tank Vapor Monitoring Program. DNFSB Recommendation 90-7.3 is closed.

- Planned Work For Subsequent Months. None.

- Problem Areas and Actions Taken. None.

- Milestone Status. None

\subsubsection{Continuous Gas Monitoring}

The possibility that localized concentrations or stratification of gases exist in the tanks was evaluated. A modeling study was conducted to determine airflow patterns in the headspace of tank 241-C-109 and evaluate the amount of mixing and the local gas concentrations that could occur. The study revealed that the gases in the tank are well mixed and follow Graham's law for gaseous diffusion; therefore, an analysis of a second tank was considered unnecessary (Wood 1992). Studies completed since that time (Claybrook and Wood 1994, Postma et al. 1994b) also confirm that conclusion.

\footnotetext{
${ }^{3}$ Trademark of Drägerwerk Aktiengesellschaft, Inc., Lubeck, Germany; also National Draeger, Inc., Pittsburgh, Pennsylvania.

${ }^{4}$ Trademark of Molectrics, Inc., Cleveland, Ohio.
} 
The need for continuous gas monitoring was addressed in a report that also assessed the potential for cyclic venting and the possibility of accumulating flammable gases (Fowler and Graves 1994). The report concluded that continuous flammable gas monitoring in ferrocyanide tanks was not warranted based on (1) the low concentration of flammable gases found to date; (2) anticipated low ferrocyanide concentrations because of waste aging; (3) analytical results from tanks $241-\mathrm{C}-109$ and $-\mathrm{C}-112$ showing that the fuel concentration in the tanks is much lower than postulated by flowsheet values and operating records; and (4) calculations of hydrogen accumulation using realistic generation values and passive ventilation assumptions. Vapor sampling of all 18 ferrocyanide tanks has corroborated that flammable gas concentrations in the ferrocyanide tanks are too low to be of concern. No further activities are planned for this task.

- Progress During Reporting Period. None.

- Planned Work For Subsequent Months. This task is complete. DOE has concurred that no continuous gas monitoring is required (O'Leary 1994).

- Problem Areas and Actions Taken. None.

- Milestone Status. None

\subsection{FERROCYANIDE WASTE CHARACTERIZATION}

"The program of sampling the contents of these tanks should be greatly accelerated. The proposed schedule whereby analysis of two core samples from each single-shell tank is to be completed by September 1998 is seriously inadequate in light of the uncertainties as to safety of these tanks. Furthermore, additional samples are required at several radii and at a range of elevations for the tanks containing substantial amounts of ferrocyanide."

Characterization of the waste in the ferrocyanide tanks is necessary to (1) guide further chemical reaction studies with the ferrocyanide waste simulants, if necessary; (2) determine actual waste chemical and physical properties; (3) determine how the ferrocyanide waste can be safely stored until retrieval and disposal actions are completed; and (4) apply the study results to the final remediation (exhumation and vitrification) of the waste. This information will be used to resolve the Ferrocyanide Safety Issue.

The important reactive materials present in the ferrocyanide tanks are fuel (ferrocyanides, sulfides, and reduced carbon species such as organic complexants), oxidants (nitrates and nitrites), and inerts or diluents (including phosphates, aluminates, sulfates, carbonates, oxides, hydroxides, and most importantly water). The location of fission products such as ${ }^{137} \mathrm{Cs}$ and ${ }^{90} \mathrm{Sr}$ is important because these products are heat sources and potential source terms in postulated radiological releases from a hypothetical ferrocyanide reaction. The water content of the waste is very important because water's high heat capacity and heat of vaporization make it an effective inerting material. Water can prevent a sustained 
combustion or a propagating reaction if sufficient fuel is present; wet ferrocyanide material would require drying before it could react or propagate.

\subsubsection{Ferrocyanide Tank Waste Sampling and Analyses}

Tank Sampling. Rotary-mode and push-mode sampling capabilities and auger surface sampling are used to obtain waste samples from the Watch List tanks. Tanks without saltcake and with relatively soft waste solids can be sampled by the push-mode method. If a hard saltcake or sludge layer is present, rotary-mode sampling is used. Auger sampling may also be used if the depth of waste is nominally less than $60 \mathrm{~cm}$.

Each core consists of several 48-cm segments (or portions thereof) depending on the depth of the waste in the tank. The sludge layer in these cores is normally divided into four 12-cm subsegments if a full $48-\mathrm{cm}$ segment is obtained; otherwise the sample is subdivided into one or more subsegments that are at least $12 \mathrm{~cm}$ in length. If the tank contains a saltcake layer, the saltcake segments are divided into only two subsegments. Segments that contain both sludge and saltcake are divided such that the two types of waste are separated into separate samples. Process flowsheet knowledge, tank historical data, and results obtained from tests with ferrocyanide sludge simulants are used to supplement the analytical results from core sampling.

The priority for sampling ferrocyanide tanks was changed to reflect the need to determine the reactive properties of the contents. In response to DNFSB Recommendation 93-5 (DOE 1994a) to expedite sampling and analyses required to address safety issues in the Hanford Site Watch List tanks, the analysis plans for future ferrocyanide tank core samples (and the plans for other Watch List tanks) were revised. The Watch List tanks were given priority for core sampling, and the number of required analytes was reduced. Analyte selection was refocused primarily on safety-related properties.

- Progress During Reporting Period. Analytical analyses are proceeding on samples obtained last quarter from two full-depth cores in risers 5 and $11 \mathrm{~A}$ (cores 116 and 117, respectively) of ferrocyanide tank 241-BY-104. Samples obtained met the requirements specified in the Ferrocyanide Data Quality Objective (DQO) document (Meacham et al. 1995). The 45-day analytical report (Benar 1996) was issued this quarter and the 105-day final analytical report is expected early next quarter. Moisture, energy (heat of reaction), total organic carbon (TOC), and total cyanide ( $\left.\mathrm{CN}^{-}\right)$for cores 116 and 117 are shown in Tables 3-1 and 3-2. Except for water, all values are reported on a dry weight basis.

Samples from the attempts to push-mode core sample tanks 241-BY-105 (riser 12A/core 108) and -BY-106 (riser 5/core 121) are also being analyzed even though the sampling event did not meet the Ferrocyanide DQO requirements. These two tanks were sampled last quarter but no sludge segments were 
recovered because the downforce limit was reached and sampling was stopped. Although some waste was collected, further sampling was postponed until the rotary-mode sampling method is approved for potential flammable gas tanks. Note that flammable gas controls were placed on all 177 Hanford Site high-level waste tanks in November 1995. An SA is being prepared for rotary mode sampling, but authorization to proceed is not expected until late next quarter at the earliest. THe 45-day analytical reports for tanks 241-BY-105 and -BY-106 have been issued (Sasaki 1996, Bell 1996). Final 105-day analytical reports for the 241-BY-105 and -BY-106 samples obtained will be available next quarter. Since neither of these cores extended to the sludge portion of the tank waste, no tabular results will be presented in this report. Some exotherms were detected, two of which exceeded the $480 \mathrm{~J} / \mathrm{g}$ notification limit, however, corresponding TOC and total cyanide values are still being determined. Results will be tabulated next quarter.

- Planned Work For Subsequent Months. The next ferrocyanide tanks scheduled for sampling are, in order, 241-TY-103, -TX-118, -BY-105, and $-\mathrm{BY}-103$. These tanks require rotary-mode sampling. The final analytical reports for tanks 241-BY-104, -BY-105, and -BY-110 were delayed this quarter and should be issued next quarter. The final report for 241-BY-106 will also be issued next quarter. Rotary mode sampling is not expected to start until late next quarter or early the following quarter.

- Problem Areas and Actions Taken. Flammable gas Watch List controls were imposed on all 177 high-level waste tanks in November 1995, as sound management practice. Consequently, any tanks that require rotary mode sampling to obtain core samples cannot be sampled until the SA has been prepared and approved by DOE. The SA is being prepared by LANL and should be completed and transmitted to DOE in early April for approval. Rotary-mode sampling of tanks 241-TY-103, -TX-118, -BY-105, and -BY-103 has been delayed until the SA is approved. Because of these controls, it will not be possible to meet the milestone dates shown below.

- Milestone Status.

- September 30, 1995. Westinghouse Hanford Company completes data interpretation reports, available for public release, for four ferrocyanide tanks. Three reports for tanks 241-C-108, -C-111, and -TY-104 were completed by September 30, 1995 (Sasaki 1995, Kelly 1995a, 1995b). Because of delays in obtaining rotary-mode core samples from tank 241-BY-108, the fourth report was not completed until February 1996 (Baldwin et al. 1996a, 1996b). 
Table 3-1. Tank 241-BY-104 Waste Sample (Averaged) Data for Core 116.

\begin{tabular}{|c|c|c|c|c|c|}
\hline $\begin{array}{l}\text { Segment } \\
\text { Number }\end{array}$ & $\begin{array}{l}\text { Subsegment - } \\
\text { Type of Waste }\end{array}$ & $\begin{array}{l}\text { Water } \\
\text { (wt\%) }\end{array}$ & $\begin{array}{c}\text { Energetics - } \\
\text { dry basis } \\
(\mathrm{J} / \mathrm{g})\end{array}$ & $\begin{array}{c}\text { TOC } \\
\text { (dry wt\%) }\end{array}$ & $\begin{array}{c}\text { Cyanide } \\
\text { (dry wt\%) }\end{array}$ \\
\hline 1 & No Sample & --- & $\ldots$ & $\cdots$ & -- \\
\hline 2 & $\begin{array}{c}\text { UH - Saltcake } \\
\text { QA - Sludge }\end{array}$ & $\begin{array}{l}10 \\
16\end{array}$ & $\begin{array}{l}22 \\
69\end{array}$ & 3.1 & $\begin{array}{c}0 \\
<0.002\end{array}$ \\
\hline 3 & $\begin{array}{l}\text { UH - Saltcake } \\
\text { LH - Saltcake }\end{array}$ & $\begin{array}{l}11 \\
11\end{array}$ & $\begin{array}{l}6 \\
0\end{array}$ & $\overline{0.5}$ & $\begin{array}{l}<0.001 \\
<0.001\end{array}$ \\
\hline 4 & $\begin{array}{l}\text { QA - Sludge } \\
\text { QB - Sludge } \\
\text { QC - Sludge }\end{array}$ & $\begin{array}{l}21 \\
21 \\
34\end{array}$ & $\begin{array}{l}0 \\
0 \\
0\end{array}$ & $\begin{array}{l}0.7 \\
0.8 \\
0.9\end{array}$ & $\begin{array}{l}0 \\
0 \\
0\end{array}$ \\
\hline 5 & $\begin{array}{l}\text { QA - Sludge } \\
\text { QB - Sludge } \\
\text { QC - Sludge } \\
\text { QD - Sludge }\end{array}$ & $\begin{array}{l}24 \\
21 \\
28 \\
23\end{array}$ & $\begin{array}{c}0 \\
300 \\
0 \\
510\end{array}$ & $\begin{array}{l}0.8 \\
0.8 \\
0.8 \\
0.8\end{array}$ & $\begin{array}{l}0 \\
0 \\
0 \\
0\end{array}$ \\
\hline 6 & $\begin{array}{l}\text { QA - Sludge } \\
\text { QB - Sludge } \\
\text { QC - Sludge } \\
\text { QD - Sludge }\end{array}$ & $\begin{array}{l}28 \\
32 \\
14 \\
24\end{array}$ & $\begin{array}{c}41 \\
100 \\
0 \\
0\end{array}$ & $\begin{array}{l}0.7 \\
0.6 \\
0.6 \\
0.8\end{array}$ & $\begin{array}{l}0 \\
0 \\
0 \\
0\end{array}$ \\
\hline 7 & $\begin{array}{l}\text { QA - Sludge } \\
\text { QB - Sludge } \\
\text { QC - Sludge } \\
\text { QD - Sludge }\end{array}$ & $\begin{array}{l}26 \\
27 \\
29 \\
26\end{array}$ & $\begin{array}{c}140 \\
350 \\
0 \\
460\end{array}$ & $\begin{array}{l}0.9 \\
1.0 \\
1.2 \\
1.7\end{array}$ & $\begin{array}{c}0 \\
0 \\
0 \\
<0.008\end{array}$ \\
\hline 8 & $\begin{array}{l}\text { QA - Sludge } \\
\text { QD - Sludge }\end{array}$ & $\begin{array}{l}27 \\
34\end{array}$ & $\begin{array}{c}810 \\
0\end{array}$ & $\begin{array}{l}2.0 \\
1.1\end{array}$ & $\begin{array}{l}<0.010 \\
<0.002\end{array}$ \\
\hline
\end{tabular}

a The samples are divided into subsegments (A - D), and are in sequence with " $A$ " being the top and " $D$ " being the bottom quarter segment. If a subsegment letter is not listed, no solids were obtained from that location of the segment.

$\mathrm{UH}=$ upper half

$\mathrm{LH}=$ lower half

$\mathrm{QA}=$ quarter segment $\mathrm{A}$

$$
\begin{aligned}
& \mathrm{QB}=\text { quarter segment } \mathrm{B} \\
& \mathrm{QC}=\text { quarter segment } \mathrm{C} \\
& \mathrm{QD}=\text { quarter segment } \mathrm{D}
\end{aligned}
$$


Table 3-2. Tank 241-BY-104 Waste Sample (Averaged) Data for Core $117^{\mathrm{a}}$.

\begin{tabular}{|c|c|c|c|c|c|}
\hline $\begin{array}{l}\text { Segment } \\
\text { Number }\end{array}$ & $\begin{array}{l}\text { Subsegment - } \\
\text { Type of Waste }\end{array}$ & $\begin{array}{l}\text { Water } \\
\text { (wt\%) }\end{array}$ & $\begin{array}{c}\text { Energetics - } \\
\text { dry basis } \\
(\mathrm{J} / \mathrm{g})\end{array}$ & $\begin{array}{c}\text { TOC } \\
\text { (dry wt \%) }\end{array}$ & $\begin{array}{c}\text { Cyanide } \\
\text { (dry wt\%) }\end{array}$ \\
\hline 1 & $\begin{array}{c}\text { DL } \\
\text { UH - Saltcake }\end{array}$ & $\begin{array}{l}49 \\
37\end{array}$ & $\begin{array}{l}0 \\
0\end{array}$ & $\begin{array}{l}0.4 \\
---\end{array}$ & $\begin{array}{c}<0.002 \\
0\end{array}$ \\
\hline 2 & $\begin{array}{c}\mathrm{DL} \\
\mathrm{QA} \text { - Sludge } \\
\mathrm{QD} \text { - Sludge }\end{array}$ & $\begin{array}{l}49 \\
29 \\
36\end{array}$ & $\begin{array}{c}0 \\
0 \\
21\end{array}$ & $\begin{array}{l}0.5 \\
0.5 \\
1.6\end{array}$ & $\begin{array}{c}<0.002 \\
0 \\
0\end{array}$ \\
\hline 3 & $\begin{array}{l}\text { UH - Saltcake } \\
\text { QC/D - Sludge }\end{array}$ & $\begin{array}{l}37 \\
27\end{array}$ & $\begin{array}{l}0 \\
0\end{array}$ & $\overline{0.9}$ & $\begin{array}{c}0 \\
<0.003\end{array}$ \\
\hline 4 & UH - Saltcake & 14 & 0 & -- & 0 \\
\hline 5 & $\begin{array}{l}\text { QA - Sludge } \\
\text { QC - Sludge }\end{array}$ & $\begin{array}{l}17 \\
16\end{array}$ & $\begin{array}{l}0 \\
0\end{array}$ & $\begin{array}{l}0.4 \\
0.4\end{array}$ & $\begin{array}{l}0 \\
0\end{array}$ \\
\hline
\end{tabular}

a The samples are divided into subsegments (A - D), and are in sequence with " $A$ " being the top and " $D$ " being the bottom quarter segment. If a subsegment letter is not listed, no solids were obtained from that location of the segment.
UH $=$ upper half
$\mathrm{QB}=$ quarter segment $\mathrm{B}$
LH $=$ lower half
$\mathrm{QC}=$ quarter segment $\mathrm{C}$
$\mathrm{DL}=$ drainable liquid
$\mathrm{QD}=$ quarter segment $\mathrm{D}$
$\mathrm{QA}=$ quarter segment $\mathrm{A}$

- December 31, 1995. Westinghouse Hanford Company obtains core samples from five additional ferrocyanide tanks. Only one ferrocyanide tank, 241-BY-104, was successfully sampled in November 1995. Attempts to obtain push mode core samples from tanks 241-BY-105 and -BY-106 were discontinued when the downforce limit was reached for the drill string. Sampling of these two tanks and others on the Watch List has been deferred until the rotary mode method is approved by DOE. The current schedule shows rotary mode sampling restarting in July 1996. 
- March 31, 1996. Westinghouse Hanford Company completes data interpretation reports, available for public release, for five ferrocyanide tanks. This milestone date was not met because of the delays encountered in rotary-mode sampling of the tanks. No date for completion of this milestone is forecast at this time because of the uncertainty in restart of rotary mode sampling.

- July 31, 1996. Westinghouse Hanford Company obtains core samples from the remaining ferrocyanide tanks. This milestone date will not be met because of the delays encountered in rotary-mode sampling of the tanks.

- October 31, 1996. Westinghouse Hanford Company completes data interpretation reports, available for public release, for the remaining ferrocyanide tanks. This milestone date cannot be met because of the current delay in obtaining core samples from the tanks.

Infrared Spectroscopy Analyses. The collection of near-infrared (NIR) spectra from archived waste tank waste core samples with various chemical matrices using a Fourier transform infrared spectrometry-based fiber optics method was completed in FY 1995.

Final reports summarizing infrared work were issued at the end of FY 1995 (Rebagay et al. 1995, Reich et al. 1995, Douglas and Reich 1995).

- Progress During Reporting Period. This task was completed in FY 1995.

- Planned Work For Subsequent Months. No further work is planned in this area in support of the Ferrocyanide Safety Program.

- Problem Areas and Actions Taken. None.

- Milestone Status. None.

Mössbauer Spectroscopy. A small task on Mössbauer spectroscopy previously supported by the Ferrocyanide Safety Program is investigating the physical and chemical nature of iron within tank waste. The National Aeronautics and Space Administration (NASA) has developed a miniaturized Mössbauer spectrometer that is small enough to perform elevation scans within the liquid observation wells (LOWs) of the Hanford Site waste tanks. Iron is a major constituent of ferrocyanide waste, and information about its location and composition in the tanks supports safe interim storage and eventual retrieval of the waste. The Mössbauer program represents a cooperative venture between Westinghouse Hanford Company, DOE, and NASA. The contact at NASA is Dr. Richard Morris at the Johnson Space Center in Houston, Texas. 
A decision was made this quarter to delete the scope of work in this task from the Ferrocyanide Safety Program and a financial Change Request was approved. The task is continuing at the Hanford Site under a funding source different from the Ferrocyanide Safety Program. Progress will no longer be reported in this quarterly report.

- Progress During Reporting Period. Funding from the Ferrocyanide Safety Program for this task was terminated this quarter when a financial Change Request was approved by Westinghouse Hanford Company and DOE-RL). The task was deleted from the scope of Ferrocyanide Safety Program because completion of the effort is not required to resolve the Ferrocyanide Safety Issue planned by the end of FY 1966. The Mössbauer spectrometer task is continuing under a separate funding source, however no further progress will be reported in the ferrocyanide quarterly reports.

- Planned Work for Subsequent Months. Work previously defined for this task is continuing, but progress will not be reported in this quarterly report.

- Milestone Status.

- September 30, 1995. Westinghouse Hanford Company issues a report, available for public distribution, on the Mössbauer spectroscopy program results for FY 1995. This milestone was completed on schedule (Riedel 1995).

- May 31, 1996. Westinghouse Hanford Company completes a second hot cell test and at least one scan in an LOW using the improved Mössbauer spectrometer, if sufficient funding is available; and issues a final report, available for public distribution, on the Mössbauer spectroscopy program. This milestone has been deleted from the scope of the Ferrocyanide Safety Program.

Scanning Electron Microscopy. Scanning electron microscopy is a small task that is investigating the chemical and physical properties of waste stored in the Hanford Site highlevel waste tanks. Studies to further refine what is known about the chemical and physical properties of ferrocyanide tank waste could continue if they were necessary for resolving the Ferrocyanide Safety Issue. However, it has been shown with confidence that the ferrocyanide concentration once placed in the tanks has significantly degraded (aged) to the point where the fuel value is much too low to support a propagating reaction. The task now at hand is to prepare a final technical basis safety document that will resolve the Ferrocyanide Safety Issue by September 1996 so that the 18 tanks can be removed from the Watch List. 
A decision was made this quarter to delete the scope of work in this task from the Ferrocyanide Safety Program and a financial Change Request was approved. The task is continuing at the Hanford Site under a funding source different from the Ferrocyanide Safety Program. Progress will no longer be reported in this quarterly report.

- Progress During Reporting Period. Funding from the Ferrocyanide Safety Program for this task was terminated this quarter when a financial Change Request was approved by WHC and DOE-RL. The task was deleted from the scope of Ferrocyanide Safety Program because completion of the effort is not required to resolve the Ferrocyanide Safety Issue planned by the end of FY 1966. The SEM task is continuing under a separate funding source, however further progress will not be reported in the ferrocyanide quarterly reports.

- Planned Work For Subsequent Months. Work previously defined for this task is continuing, but progress will not be reported in this quarterly report.

- Milestone Status.

- September 29, 1995. Westinghouse Hanford Company issues a report, available for public release, on SEM program results for FY 1995. A report was issued on schedule (Callaway 1995).

- March 29, 1996. Westinghouse Hanford Company issues a final report on SEM technology development. This milestone was not completed because the radiologically-controlled facility for doing SEM scans on radioactive materials was not ready in time. This milestone has been deleted from the scope of the Ferrocyanide Safety Program.

\subsubsection{Estimation of Water Content}

Methods for determining water concentrations in Hanford Site waste tanks are being developed using sample data analyses and state-of-the-art surveillance systems. This work was originally sponsored by the Ferrocyanide Safety Program, but it was transferred to the Organic Safety Program at the beginning of FY 1996. Two in situ moisture monitoring technologies are currently under development: neutron diffusion and electromagnetic induction (EMI). Initial development of NIR spectroscopy for determining the water content of Hanford Site tank waste was completed in FY 1994 (Reich et al. 1994) at the University of Washington Center for Process Analytical Chemistry and by WHC in FY 1995 (Rebagay et al. 1995, Reich et al. 1995). A report examining moisture monitoring technologies was completed in April 1993 (Meacham et al. 1993).

The water content of reactive waste can be an extremely important factor in ensuring the safety of the Hanford Site tank waste. The water concentration within the waste will determine whether or not it will react and propagate. If sufficient water is present, a 
chemical reaction cannot start. Recent work by FAI (Fauske 1996) has shown that as little as 5 wt\% unbound water in a stoichiometric reactive mixture will prevent the mixture from igniting and burning when a significant ignition source is applied. Water may become the prime safety factor for the organic waste tanks to ensure that the waste is stored safely. For the ferrocyanide tanks it has been shown that the ferrocyanide content is insufficient for the waste to propagate, so the presence of water becomes a second safety barrier ensuring that the tanks are safe.

Neutron Diffusion. Well-logging techniques, coupled with computer modeling, were developed and applied to an existing neutron probe to determine information about the water concentrations, material interfaces, and other waste characteristics in the ferrocyanide tanks. Using the knowledge gained from computer modeling, in situ measurements, and experimental calibration data with the current in-tank liquid level neutron probe (Watson 1993), prototype moisture measurement neutron probes were developed. This system consists of three neutron probes: a near-field thermal neutron probe, a far-field thermal neutron probe, and a far-field epithermal neutron probe. This improved system would primarily be used to determine the axial moisture concentration profile within the ferrocyanide tanks.

Moisture measurement using neutron diffusion is an established technology. The technique uses a neutron source and one or more neutron detectors. The thermal neutrons reaching a detector originate as fast neutrons from the source and are slowed or absorbed by the medium. Because hydrogen atoms are effective at slowing down neutrons, the detector response is a strong function of the surrounding moisture concentration.

Two methods are generally used in the measurement of moisture concentration around wells using neutron diffusion. The first method, the moisture gauge, has a short source-to-detector spacing (near field) on the order of 0 to $10 \mathrm{~cm}$. The response of a moisture gauge is characterized by an increase in detector response with increasing moisture concentration of the surrounding medium. The second method, the neutron $\log$, often has two detectors with longer source-to-detector spacings: 20 to $50 \mathrm{~cm}$ (far field). The detectors in a neutron log arrangement exhibit a decreased response to increased moisture concentrations. The detector placed at the shorter spacing is used to correct the response of the longer-spaced detector for borehole effects.

Tank moisture measurements are taken from within LOWs. The LOWs are permanently installed sealed pipes that extend from the riser top through the tank waste to near the tank bottom. The LOWs allow axial information about the surrounding waste materials to be obtained using certain detectors.

The initial design and prototype tests were completed for a new surface moisture measurement neutron probe in FY 1995. Results and progress on this task are reported in Watson (1993), Finfrock et al. (1994), and (Lipke 1995). This effort was transferred to the Organic Safety Program, and no additional development work will be conducted for the Ferrocyanide Safety Program. 
- Progress During Reporting Period. This task was transferred to the Organic Safety Program at the end of FY 1995, and progress on this ongoing task is no longer reported in this document.

- Planned Work for Subsequent Months. Not applicable.

- Milestone Status. Not applicable.

Electromagnetic Induction Probe. The purpose of this task is to deploy the EMI probe in the LOWs or on top of the waste surface to measure moisture concentration. EMI probes operate by creating a magnetic field that induces current in a conductive medium. This induced current can be measured and is related to the media conductivity. The higher the electrical conductivity, the higher the free moisture content in the tank waste.

The EMI probe is designed with four separate coils of wire that can be either exciting coils or sensing coils. The present configuration uses one coil as the exciting coil and three coils as the sensing coils. This configuration allows three different depths of penetration during one scan. The electronics can be programmed to use four frequencies during one scan, so the information acquired will be four frequencies at three different coil spacings. This information will be useful in separating the environment near the LOW from the environment far from the LOW. Two different EMI probes have been built, with different coil spacing and turns per coil, to determine in-tank responses.

EMI probes were deployed in tanks 241-BY-104, -BY-106, -BY-107, -BY-111, -BY-112, -TY-103, -TX-118, -TX-114 (3 LOWs), -S-105, and -S-106. Observations of the in-tank acquired data allowed some conclusions about EMI to be made: (1) the system is sensitive to loss of hydraulic conductivity, which occurs about 0.08 to 0.12 volume fraction of liquid, depending on porosity; (2) the scan can interrogate multiple depths simultaneously; (3) EMI is sensitive to small changes in material properties; (4) EMI method measures conductivity directly, while moisture interpretation requires some assumptions; (5) EMI results are affected by temperature, so compensation is required; and (6) EMI method is strongly affected by ferromagnetic items. A report was issued in September 1995 (Crowe and Wittekind 1995). The remaining development effort was transferred to the Organic Safety Program at the end of FY 1995.

- Progress During Reporting Period. None. This task was transferred to the Organic Safety Program at the end of FY 1995.

- Planned Work for Subsequent Months. None.

- Problem Areas and Action Taken. None.

- Milestone Status. None. 


\subsubsection{Moisture Retention Properties of Ferrocyanide Sludge and Saltcake Simulants}

The water content of ferrocyanide sludge, if sufficient, will prevent exothermic ferrocyanide/nitrate-nitrite reactions. Studies were completed to evaluate the water retention properties of ferrocyanide tank sludge and saltcake simulants as they relate to possible waste tank leaks, tank stabilization by pumping, and possible evaporation from exposed surfaces. Previous work (Epstein et al. 1994) has shown that ferrocyanide sludge cannot dry sufficiently to be chemically reactive during interim storage, either globally or locally. Dryout mechanisms evaluated included global evaporation, removal of liquid by leakage or pumping, boiling as a result of hot spots, and enhanced surface evaporation from hot spots. Recent work focused on water retention in saltcake material, especially after a tank has been interim stabilized. This work was supported by the Ferrocyanide Safety Program until the end of FY 1995 but was transferred to the Organic Safety Program at the beginning of FY 1996.

Modeling calculations were performed to estimate the water-retaining capability of ferrocyanide waste in typical Hanford Site tank systems. The effort focused on evaluating the impact of consolidation and surface evaporation processes. Computer models were used to estimate retention of water within the matrix and to determine surface drying of sludge and saltcake waste. To accomplish these objectives, the hydraulic properties of actual sludges and saltcake porous media were compared with tested waste simulants, and their physical properties were correlated.

Modeling was also performed to examine the resistance of saltcake waste to gravity drainage and surface evaporation. Under gravity's influence, saturated saltcake will drain when liquid is pumped out and when a tank is stabilized. In contrast, sludge does not readily drain and the interstitial liquid must be expelled by consolidation, usually caused by an overburden. Because saltcake drains when stabilized, it is more subject to potential drying at the surface as a result of water evaporation.

Modeling of the water retention properties of saltcake and sludge waste was completed and documented in September 1995 (Simmons 1995). Water retention modeling for the Ferrocyanide Safety Program has been completed. However, additional saltcake modeling continues for the Organic Safety Program.

- Progress During Reporting Period. None.

- Planned Work for Subsequent Months. None.

- Milestone Status. None. 


\subsection{CHEMICAL REACTION STUDIES}

"The schedule for the program on study of the chemical properties and explosive behavior of the waste in these tanks is indefinite and does not reflect the urgent need for a comprehensive and definitive assessment of the probability of a violent chemical reaction. The study should be extended to other metallic compounds of ferrocyanide that are known or believed to be present in the tanks, so that conclusions can be generalized as to the range of temperature and other properties needed for a rapid chemical reaction with sodium nitrate."

Chemical reaction studies on ferrocyanide waste simulants have been conducted by Westinghouse Hanford Company, FAI, PNNL, and Los Alamos National Laboratory. Only the PNNL program was on-going during this quarter; all the other programs have been completed. Both Westinghouse Hanford Company and PNNL have produced flowsheet simulant materials for testing and characterization. Earlier, FAI conducted adiabatic calorimetry and propagation tests on these same flowsheet materials and on stoichiometric mixtures of pure sodium nickel ferrocyanide and sodium nitrate/nitrite. The test program at Los Alamos National Laboratory evaluated the sensitivity of ferrocyanide reactions to shock, friction, and thermal aging (Cady 1993); the program was completed in FY 1993.

\subsubsection{Chemical Reaction Studies at Pacific Northwest National Laboratory}

Chemical reaction studies are nearing completion at PNNL using flowsheet simulant materials. Waste studies addressing DNFSB Recommendation 90-7.5 have been conducted to determine the following: (1) aging effects (hydrolysis and radiolysis) from more than 35 years of storage in the tanks; (2) reaction kinetics and properties of various mixtures of ferrocyanide with sodium nitrate and/or sodium nitrite; (3) comparison of waste simulant and actual waste properties; and (4) modeling calculations to predict the moisture-retaining capability of ferrocyanide waste in a typical tank system. All of these tasks are complete except for the aging effects studies.

- Progress During Reporting Period.

Aging Studies. Formate ion is one of the products of ferrocyanide aging. In previous work, radiolysis of formate was observed but the product was not identified. Recent experiments have now shown that radiolysis of formate ion forms carbonate ion. These experiments were conducted by irradiating NMR tubes containing $0.1 M \mathrm{NaNO}_{3}, 0.03 M \mathrm{NaNO}_{2}$, and $0.03 M \mathrm{NaH}^{13} \mathrm{CO}_{2}$ in $2 M$ $\mathrm{NaOH}$ solution at a dose rate of about $1 \times 10^{5} \mathrm{Rad} / \mathrm{h}$. The results are shown in Figure 3-1. Formate decomposed under these conditions in an apparently 0 -order (or linear) fashion at a rate of $5.7 \times 10^{-3} \mathrm{moles} / \mathrm{L} /$ day. Carbonate ion appeared at the same rate and no other ions, including oxalate, were observed. The rate of radiolysis of formate is about five times faster than that for radiolysis 
of ammonia. Further experiments are being conducted at a lower dose rate and at a higher initial formate concentration.

Another intermediate product that forms during aging of sodium nickel ferrocyanide is tetracyanonickelate ion, $\mathrm{Ni}(\mathrm{CN})_{4}^{-2} . \mathrm{Ni}(\mathrm{CN})_{4}^{-2}$ apparently forms when free $\mathrm{CN}^{*}$, liberated as $\mathrm{Fe}(\mathrm{CN})_{6}^{4}$ ages, redissolves $\mathrm{Ni}(\mathrm{OH})_{2}$. This ion was studied at two temperatures and two dose rates for comparison to $\mathrm{Na}_{2} \mathrm{NiFe}(\mathrm{CN})_{6}$ aging. Figure 3-2 shows that the rate of ammonia production by hydrolysis increased with both increasing gamma dose rate and temperature, as expected.

Table 3-3 shows that the rate constants obtained from these data by assuming a 0 -order (linear) increase in ammonia concentration are about the same as those obtained for aging of In-Farm waste simulant (Jeppson and Wong 1993). One reason for this could be that the hydrolysis of either free cyanide or $\mathrm{Ni}(\mathrm{CN})_{4}^{-2}$ is the rate limiting step. It is also interesting to note that the rate of $\mathrm{Ni}(\mathrm{CN})_{4}^{-2}$ hydrolysis with $\mathrm{NO}_{3}^{-} / \mathrm{NO}_{2}^{-}$present is about three times faster than when these ions are absent. It is not known which ion causes this effect. Because the concentrations of both of these ions change as aging proceeds, the ammonia production rate constant also changes with time, and the apparent 0 -order behavior is likely an artifact of the changing rate.

Table 3-3. Summary of Rate Constants for Aging of $\mathrm{Ni}(\mathrm{CN})_{4}^{-2}$ and In-Farm Waste Simulant.

\begin{tabular}{|c|c|c|c|c|c|}
\hline \multirow{2}{*}{$\begin{array}{c}\text { Temperature } \\
\left({ }^{\circ} \mathrm{C}\right)\end{array}$} & \multirow{2}{*}{$\begin{array}{c}\text { Dose Rate } \\
(\mathrm{Rad} / \mathrm{h})\end{array}$} & \multicolumn{2}{|c|}{$\mathrm{Ni}(\mathrm{CN})_{4}^{-2}$} & \multicolumn{2}{c|}{ In-Farm } \\
\cline { 3 - 6 } & & Exprmt \# & $\mathrm{k}, M /$ day & Exprmt \# & $\mathrm{k}, M /$ day \\
\hline 90 & $1 \times 10^{5}$ & $\mathrm{Ni}-5,6$ & $5.3 \times 10^{-3}$ & $\mathrm{H}-1$ & $3.8 \times 10^{-3}$ \\
\hline 90 & $1 \times 10^{4}$ & $\mathrm{Ni}-3$ & $1.0 \times 10^{-3}$ & $\mathrm{H}-5$ & $1.1 \times 10^{-3}$ \\
\hline 100 & $1 \times 10^{5}$ & $\mathrm{Ni}-4,7$ & $8.6 \times 10^{-3}$ & $\mathrm{H}-11$ & $8.4 \times 10^{-3}$ \\
\hline 90 & $1 \times 10^{5}$ & $\mathrm{Ni}-1^{*}$ & $1.9 \times 10^{-3}$ & & \\
\hline
\end{tabular}

Nitrogen and hydrogen gas are formed during radiolytic aging of the In-Farm waste simulant (Figure 3-3). The 0-order rate constants for formation of $\mathrm{N}_{2}$ at $1 \times 10^{4} \mathrm{Rad} / \mathrm{h}$ and $1 \times 10^{5} \mathrm{Rad} / \mathrm{h}$ are about the same as those for the destruction of $\mathrm{NH}_{3}$ at the same dose rates. The similarity of the rate constants suggests that $\mathrm{N}_{2}$ is the product of $\mathrm{NH}_{3}$ radiolysis. However, a good correlation was not obtained for nitrogen production in aging of $\mathrm{Ni}(\mathrm{CN})_{4}^{-2}$ for which gas production was about three times slower than for the In-Farm waste simulant. The cause for the slower gas production is under investigation. 
Figure 3-1. Radiolysis of Formate Ion at $1 \times 10^{5} \mathrm{Rad} / \mathrm{h}$ in $2 \mathrm{M} \mathrm{NaOH}$ at Ambient Temperature.

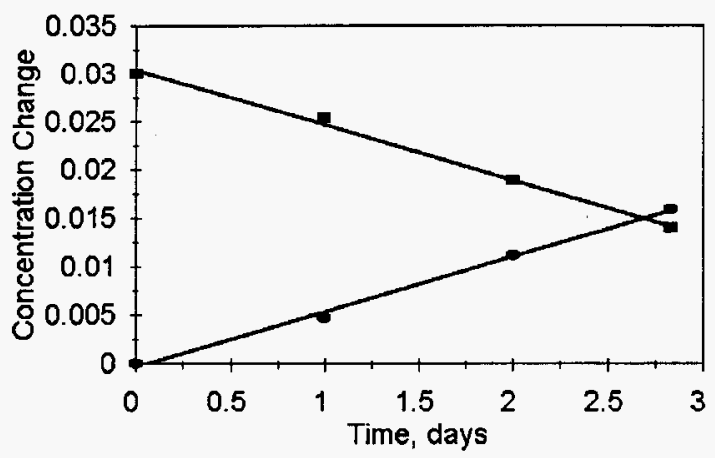

\section{- Formate - Carbonate}

Figure 3-2. Ammonia Production During Hydrolysis of $\mathrm{Ni}(\mathrm{CN})_{4}^{-2}$.

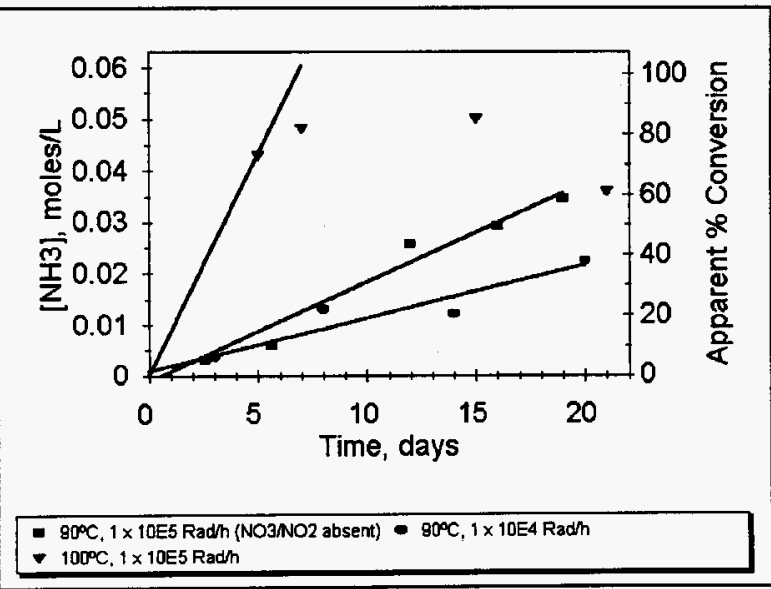


Figure 3-3. The Effect of $\mathrm{NO}_{3}{ }^{-} / \mathrm{NO}_{2}{ }^{-}$on Ammonia Production During Hydrolysis of $\mathrm{Ni}(\mathrm{CN})_{4}^{-2}$.

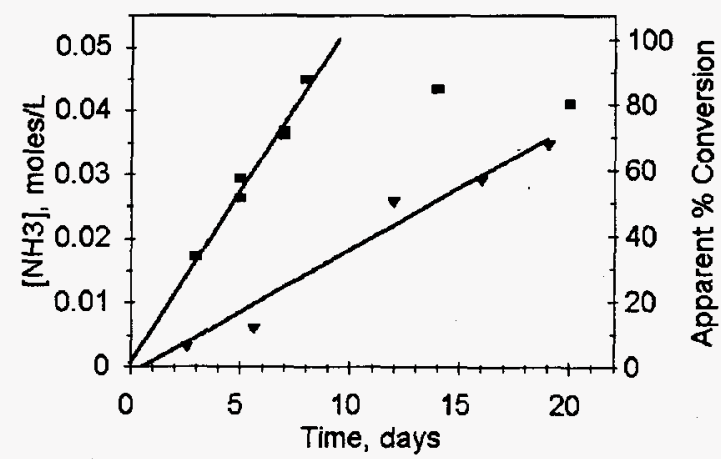

900C, $1 \times 10 E 5$ Radh (NO3NO2 present) $>900^{\circ} .1 \times 10 E 5$ Radh (NO3NO2 absent)

Figure 3-4. $\mathrm{N}_{2}$ and $\mathrm{H}_{2}$ Generation and $\mathrm{NH}_{3}$ Destruction as a Function of Dose Rate.

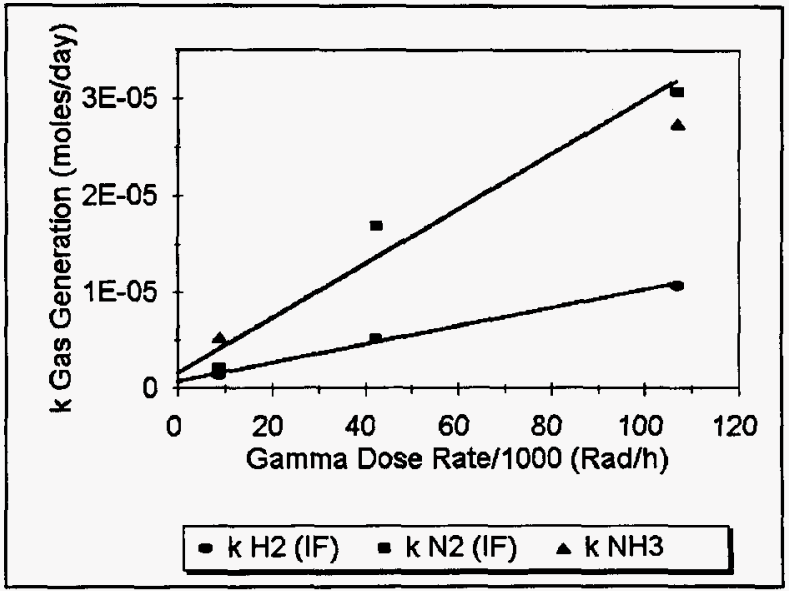


Experiments to test the reproducibility of aging results are also underway. Experiments are being conducted with the In-Farm waste simulant in $2 \mathrm{M} \mathrm{NaOH}$ at $90^{\circ} \mathrm{C}$ and $1 \times 10^{5} \mathrm{Rad} / \mathrm{h}$ for 12 days. These conditions duplicate conditions for Experiment $\mathrm{H}-1$, the first aging experiment. Results of the first set of three irradiated solutions and one control (without gamma irradiation) are shown in Figure 3-5. The amount of ammonia formed in the duplicates is the same, within about $10 \%$, as seen previously in Experiment H-1. Two more sets of experiments are being conducted to evaluate the variability arising from the use of different tubes in the gamma pit, the use of different reaction vessels, and different experimental techniques.

- Planned Work For Subsequent Months. All aging experiments and reproducibility tests planned for the Ferrocyanide Safety Program will be completed next quarter.

- Problem Areas and Actions Taken. None.

- Milestone Status.

- June 28, 1996. PNNL completes a final report, available for public release, summarizing the results of all aging experiments completed for the Ferrocyanide Safety Program. This milestone is on schedule; a draft report is scheduled to be issued to WHC for review in May 1996. This action completes the requirements of DNFSB Recommendation 90-7.5.

Figure 3-5. Reproducibility of Ammonia Production in Aging Experiments.

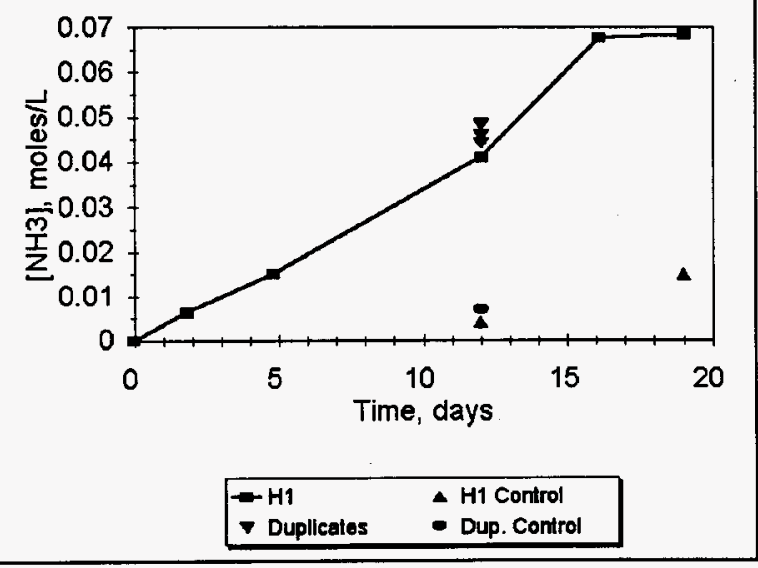




\subsubsection{Preparation and Characterization of Ferrocyanide Simulants}

Earlier in the Ferrocyanide Safety Program various ferrocyanide waste simulants were prepared and analyzed to determine their chemical reaction properties as a function temperature and water present in the mixture. Other tests were conducted with pure sodium nickel ferrocyanide, a stoichiometric amount of oxidizer (sodium nitrate/nitrite), and water. These latter tests were conducted by FAI to define the margin of safety between the theoretical and experimental propagation limits for ferrocyanide. These tests are run in the FAI reactive systems screening tool. These tests and previous tests with simulants--along with analyses of actual tank waste samples, waste tank monitoring, and waste modeling--provide information to characterize with a large degree of conservatism the safety concerns relating to the ferrocyanide sludge originally added to 18 Hanford Site waste tanks.

- Progress During Reporting Period. Work was completed this quarter on a FAI report discussing the credibility of bulk runaway reactions. The report, WHC-SD-WM-ER-543, Rev. 0, Assessment of Chemical Vulnerabilities in the Hanford High-Level Waste Tanks (Fauske 1966), was issued in February 1996. Calculations indicate that bulk runaway reactions are not possible under current storage conditions.

A financial Change Request was approved this quarter which deleted further chemical reactivity work at FAI on the Ferrocyanide Safety Issue. Further work is not required because previous chemical reaction studies and results obtained by sampling nine of the ferrocyanide tanks show that the fuel value of ferrocyanide has degraded (aged) to levels too low to be of concern.

- Planned Work for Subsequent Months. No further work is planned in this area for the Ferrocyanide Safety Program.

- Problem Areas and Actions Taken. None.

- Milestone Status.

- September 30, 1996. Complete FAI support for Ferrocyanide Safety Issue resolution and conclude chemical reactivity studies of chemical waste. This milestone was deleted by the financial Change Request approved this quarter. 


\subsection{EMERGENCY RESPONSE PLANNING}

"The Board had recommended 'that an action plan be developed for the measures to be taken to neutralize the conditions that may be signaled by alarms.' Two types of measures are implied: actions to respond to unexpected degradation of a tank or its contents, and actions to be taken if an explosion were to occur. Your implementation plan stated that 'the current contingency plans ... will be reviewed and revised if needed.' We do not consider that this proposed implementation of the Board's recommendation is adequately responsive. It is recommended that a written action plan founded on demonstrated principles be prepared as soon as possible, that would respond to indications of onset of abnormal temperatures or other unusual conditions in a ferrocyanide-bearing tank, to counter any perceived growth in hazard. A separate emergency plan should be formulated and instituted, covering measures that would be taken in event of an explosion or other event leading to an airborne release of radioactive material from the tanks, and that would protect personnel both on and off the Hanford Site. The Board believes that even though it is considered that the probability is small that such an event will occur, prudence dictates that steps be taken at this time to prepare the means to mitigate the unacceptable results that could ensue."

The original Action Plan for Response to Abnormal Conditions in Hanford Radioactive Waste Tanks Containing Ferrocyanide (Cash and Thurman 1991) was prepared in response to DNFSB Recommendation 90-7.6. The plan describes the steps to be taken if a temperature increase trend above the tank temperature baseline is measured in any of the ferrocyanide tanks. The document was revised (Cash and Thurman 1992) to include the monitoring criteria and responses for abnormal levels of flammable and toxic gases, as well as the reporting requirements, if established criteria are exceeded. The second revision of the plan was released in June 1994 (Fowler 1994).

The Tank Farm Stabilization Plan For Emergency Response (WHC 1991) was issued in March 1991. If a radioactive release from a ferrocyanide tank were to occur, it would be detected by one or more radiation monitoring systems. Significant airborne or ground surface releases that spread beyond the immediate tank or tank farm would be detected by the tank farm area radiation detectors. These monitoring systems are on all tank farms. An emergency involving an underground radioactive waste storage tank is a unique event with potentially serious consequences both onsite and offsite. The Stabilization Plan provides quick, preplanned actions that can be used to stabilize an emergency event at an underground radioactive waste storage tank.

All actions with respect to emergency planning, emergency event recognition, protective action recommendations, and emergency response procedures have been completed. Further revisions and occasional validation exercises will be accomplished as part of the normal Westinghouse Hanford Company and DOE emergency planning efforts. No further reporting on these issues is planned, and this part of DNFSB Recommendation 90-7.6 is considered complete and closed. 
DOE considers this recommendation to be closed with the provisos that the abnormal conditions response plan and emergency plans are reviewed on a periodic basis and revised and updated as required to incorporate any additional controls determined appropriate by the ongoing Waste Tank Safety Program investigations (e.g., the Action Plan for Response to Abnormal Conditions in Hanford Site Radioactive Waste Tanks Containing Ferrocyanide was updated and released in June 1994 [Fowler 1994]); and that validation exercises for various waste tank accident scenarios are conducted periodically (exercises for the tank farms are conducted every two years).

- Progress During Reporting Period. As noted in previous reports, all of the planned milestones for this task have been completed.

- Planned Work For Subsequent Months. None planned.

- Problem Areas and Action Taken. None.

- Milestone Status. All milestones have been completed. 
This page intentionally left blank. 


\subsection{IMPLEMENTATION OF THE WYDEN AMENDMENT}

The Wyden Amendment (Public Law 101-510, Section 3137 [1990]) requires that:

"...the Secretary of Energy shall identify which single-shelled or double-shelled high-level nuclear waste tanks at the Hanford Nuclear Reservation, Richland, Washington, may have a serious potential for release of high-level waste due to uncontrolled increases of temperature or pressure. After completing such identification, the Secretary shall determine whether continuous monitoring is being carried out to detect a release or excessive temperature or pressure at each tank so identified. If such monitoring is not being carried out, as soon as practicable the Secretary shall install such monitoring, but only if a type of monitoring that does not itself increase the danger of a release can be installed."

\subsection{THE WATCH LIST}

In March 1989, using process knowledge, process records, transfer records, and log books, Westinghouse Hanford Company (Nguyen 1989) identified 22 Hanford Site tanks as potentially containing $1,000 \mathrm{~g}$-moles $(211 \mathrm{~kg}$ [ $465 \mathrm{lb}$ ]) or more of ferrocyanide [as the $\mathrm{Fe}(\mathrm{CN})_{6}^{4}$ anion]. To avert possible injury to personnel and damage to the facility or environment, strict controls were identified for these and other tanks with safety issues. These controls were described in the document, Operating Specifications for Watch List Tanks (WHC 1990). Tanks identified by this document (see WHC [1996] for latest revision) have been commonly referred to as Watch List tanks. Two additional ferrocyanide tanks were identified in January 1991 (Borsheim and Cash 1991), increasing the total number of ferrocyanide tanks to 24 .

In November 1990, the Wyden Amendment (Public Law 101-510, Section 3137 [1990]) was enacted. This law required the identification of Hanford Site tanks that may have a serious potential for release of high-level waste. In February 1991 (Harmon 1991), the 24 ferrocyanide tanks were among the tanks identified, and were included in the subsequent July 1991 report to Congress (Watkins 1991) that responded to the Wyden Amendment. However, re-examination of the historical records (Borsheim and Simpson 1991) indicated that six of the 24 tanks did not contain the requisite $1,000 \mathrm{~g}$-moles of ferrocyanide. Therefore, these six tanks should not have been included on the Watch List nor been identified in the response to the Wyden Amendment. The six tanks were subsequently removed from the Watch List (Anttonen 1993, Sheridan 1994b) (Note: these tanks do not contain greater than $8 \mathrm{wt} \% \mathrm{Na}_{2} \mathrm{NiFe}(\mathrm{CN})_{6}$ and should not be on the Watch List for this reason also).

As part of the overall safety screening module being conducted by Westinghouse Hanford Company Tank Waste Remediation System, all of the Hanford Site SSTs will be core sampled and characterized. Eighteen ferrocyanide tanks are currently on the Watch List, and no more ferrocyanide tanks are expected to be added to the Watch List. 
Work conducted since 1991 on ferrocyanide reactions has resulted in a change of the criterion used for placing ferrocyanide tanks on the Watch List. The 1,000 g-mole inventory criterion has now been replaced with a fuel concentration criterion of 115 calories per gram (cal/g) of dry sample (this is an energy equivalent to a concentration of $8 \mathrm{wt} \% \mathrm{Na}_{2} \mathrm{NiFe}(\mathrm{CN})_{6}$ in the waste). This fuel concentration criterion more accurately reflects the risk associated with ferrocyanide tanks. Ferrocyanide tanks with concentrations less than an energy equivalent of $8 \mathrm{wt} \% \mathrm{Na}_{2} \mathrm{NiFe}(\mathrm{CN})_{6}$ cannot support a propagating reaction, and are categorized as safe. Detailed rationale for the $115 \mathrm{cal} / \mathrm{g}$ of dry fuel concentration criterion is presented in Postma et al. (1994a).

Core sampling and characterization efforts will determine the ferrocyanide concentration for those tanks that bound aging (see Sections 2.2 and 3.4). After adequate characterization, if these tanks contain concentrations less than $8 \mathrm{wt} \% \mathrm{Na}_{2} \mathrm{NiFe}(\mathrm{CN})_{6}$ (i.e., the fuel value of the maximum concentration is less than $115 \mathrm{cal} / \mathrm{g}$ ), then a request will be made by Westinghouse Hanford Company for DOE concurrence to remove all the ferrocyanide tanks from the Watch List.

Some sample bias and analytical error are unavoidable; therefore, confidence intervals have been established to specify when it is appropriate to conclude that a ferrocyanide tank contains concentrations less than an energy equivalent of $8 \mathrm{wt} \% \mathrm{Na}_{2} \mathrm{NiFe}(\mathrm{CN})_{6}$. An $80 \%$ confidence interval was chosen for tanks with a fuel concentration of $8 \mathrm{wt} \%$ $\mathrm{Na}_{2} \mathrm{NiFe}(\mathrm{CN})_{6}$. That is, if five ferrocyanide tanks contain exactly an energy equivalent of $8 \mathrm{wt} \% \mathrm{Na}_{2} \mathrm{NiFe}(\mathrm{CN})_{6}$, statistically, four tanks would remain on the Watch List and one tank would be removed. The possibility of removing a ferrocyanide tank from the Watch List decreases substantially as the fuel concentration increases. The confidence intervals increase to $95 \%$ and $99 \%$ at $\mathrm{Na}_{2} \mathrm{NiFe}(\mathrm{CN})_{6}$ concentrations of $12 \%$ and $15 \mathrm{wt} \%$, respectively. Detailed discussions on how sample bias and analytical error are factored into determining the actual fuel concentrations in a ferrocyanide tank are given in the Ferrocyanide DQO (Meacham et al. 1995).

- Planned Work To Complete Program. An increased understanding of ferrocyanide degradation (aging) and its verification by analysis of core samples from nine plus ferrocyanide tanks indicates that little ferrocyanide remains. The assumption that it is necessary to core sample all ferrocyanide tanks is now longer considered to be valid. By characterizing the waste in only those tanks that bound aging (i.e., tanks with conditions least conducive to aging), the Ferrocyanide Safety Issue could be resolved much earlier and at a substantially reduced cost. Enough core sample data are now available to complete a technical basis safety document that justified removal of the tanks from the Watch List and thus, resolution of the Ferrocyanide Safety Issue.

Work on the Ferrocyanide Safety Program is drawing to a rapid close and sampling of additional tanks is not necessary to resolve the safety issue. As indicated below, preparation of the final technical basis safety document, WHC-SD-WM-SARR-038, Revision 1, is underway with submittal to DOE-RL 
planned on or before July 3, 1996. A final report on the aging test program at PNNL is also being prepared. All six parts of DNFSB Recommendation 90-7 have been adequately addressed and a letter was transmitted this quarter by DOE Headquarters to the Chairman of the DNFSB (Guimond 1996) requesting closure of the recommendation.

\section{- Milestones.}

- January 31, 1996. Westinghouse Hanford Company issues documentation supporting safety issue resolution for the four C-Farm tanks and recommends their removal from the Wyden Amendment Watch List (Public Law 101-510, 1990). Document WHC-SD-WM-SARR-038, Revision 0, Assessment of the Potential for Ferrocyanide Propagating Reaction Accidents, was transmitted to DOE-RL as scheduled (Bacon 1996a, Grigsby et al. 1996a). All four C-Farm tanks were sampled earlier and data interpretation reports have been completed for these tanks.

The report was revised to incorporate informal comments received from DOE-RL and reissued with the same title as WHC-SD-WM-SARR-038, Revision OA, (Grigsby et al. 1996b). The revised report was transmitted to DOE-RL with a letter requesting that the four C-Farm tanks be removed from the Watch List on March 19, 1996 (Bacon 1996b). The report was subsequently forwarded to the DNFSB Staff on April 10, 1996 (Trine 1996).

- July 31, 1996. Westinghouse Hanford Company receives DOE approval to remove the four C-Farm ferrocyanide tanks from the Watch List.

- March 31, 1997. Westinghouse Hanford Company prepares documentation to support resolution of the Ferrocyanide Safety Issue for the last 14 ferrocyanide tanks, and recommends Ferrocyanide Safety Issue resolution. This milestone has been accelerated to July 3, 1996; the final safety document (WHC-SD-WM-SARR-038, Revision 1) is currently being prepared and will be forwarded to DOE-RL for review next quarter.

- September 30, 1997. Westinghouse Hanford Company receives DOE approval to remove the remaining 14 ferrocyanide tanks from the Watch List and to declare the Ferrocyanide Safety Issue resolved. This action completes the Ferrocyanide Safety Program. Next quarter, in conjunction with completing the milestone above, Westinghouse Hanford Company will request that DOE complete this milestone by September 30, 1996. 


\subsection{TEMPERATURE MONITORING}

The installation of temperature monitoring capabilities is discussed in Sections 3.1.2.1 and 3.2.2. Installation of instrument trees and continuous temperature monitoring are considered prudent waste management practices. Therefore, new instrument trees will be installed in ferrocyanide tanks, even though the ferrocyanide waste has aged and little fuel value remains. Instrument trees have been installed in all ferrocyanide tanks and are continuously monitored by TMACS.

- Planned Work To Complete Program. None. This task. is complete.

- Milestones. None.

\subsection{PRESSURE MONITORING}

The ferrocyanide tanks were initially identified as having "a serious potential for release" and were placed on the Watch List because insufficient data were available on the probability for ferrocyanide-nitrate/nitrite reactions. Pressure monitoring instrumentation is not presently installed on the ferrocyanide tanks. It would take several years to install pressure monitoring instrumentation because of the capital project time cycle. Ferrocyanide waste has probably degraded (aged) significantly, and all of the tanks may now contain less than the $8 \mathrm{wt} \%$ $\mathrm{Na}_{2} \mathrm{NiFe}(\mathrm{CN})_{6}$ fuel concentration specified for the safe category (see also Postma et al. 1994a). This eliminates the need for continuous pressure monitoring for offgases from a ferrocyanide reaction.

The rationale for not installing pressure monitors in ferrocyanide tanks was prepared and submitted to DOE in July 1994 (Payne 1994b). Low gas generation rates (Fowler and Graves 1994) and the low potential for exothermic ferrocyanide reactions (Postma et al. 1994a) indicated that continuous pressure monitoring is not warranted.

- Planned Work For Subsequent Months. No additional work is planned in this area, because DOE has concurred that pressure monitoring is not required as stated in the revised Ferrocyanide Safety Issue Program Plan (O'Leary 1994).

- Milestones. None. 


\subsection{PROGRAM SCHEDULES AND MILESTONES}

Schedules (Figure 5-1) are presented in this section. The schedules review milestones for FY 1994 through the expected end of the program in FY 1997. The sequence and anticipated completion dates of the major milestones leading to resolution of the Ferrocyanide Safety Issue are presented. Closure of DNFSB recommendations are indicated on the schedule as diamonds, and completion of interim milestones are indicated as triangles. The schedules are statused through March 31, 1996. 
Figure 5-1. Ferrocyanide Waste Tank Safety Schedule. (Sheet 1 of 2)

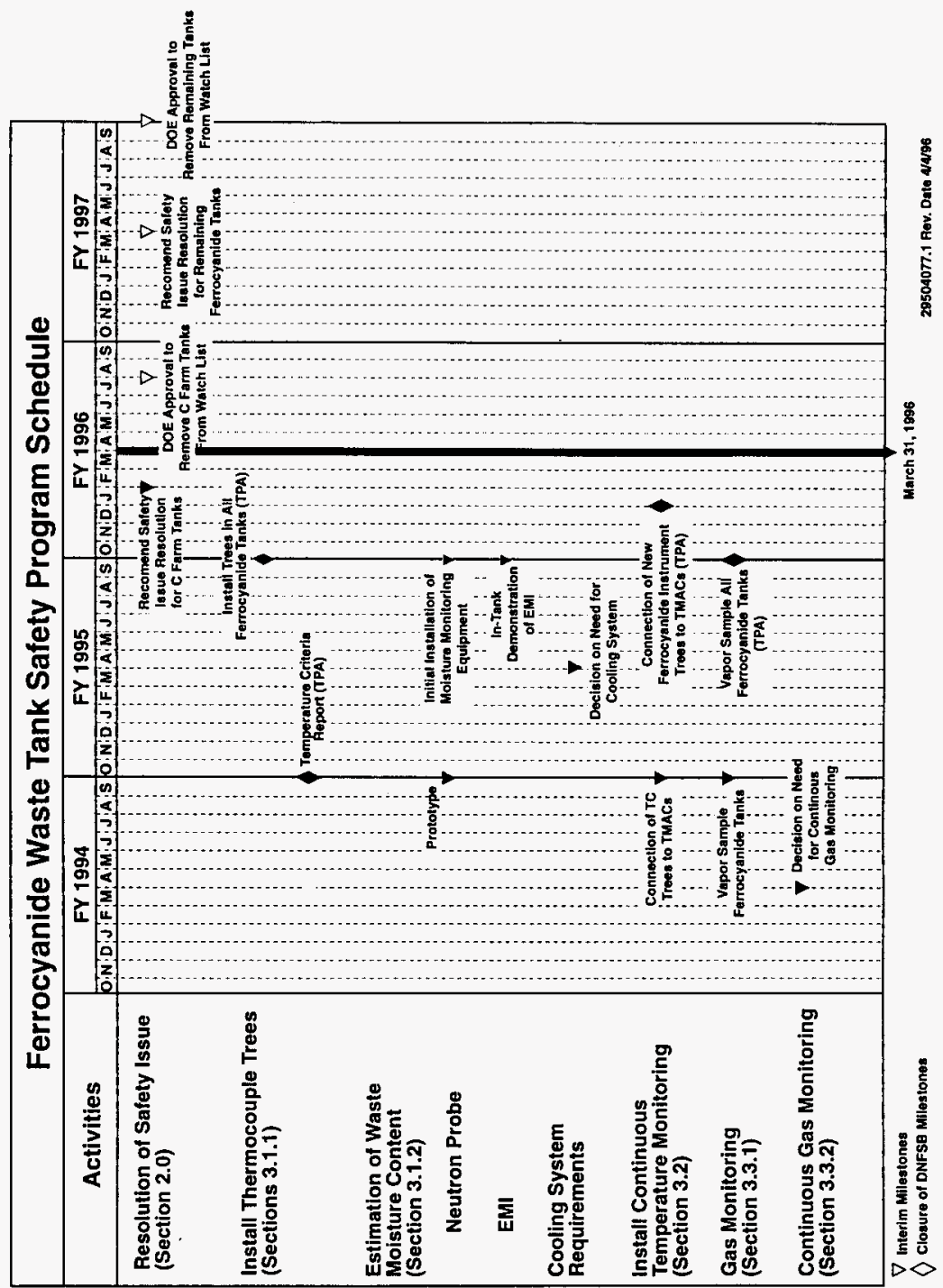


Figure 5-1. Ferrocyanide Waste Tank Safety Schedule. (Sheet 2 of 2)

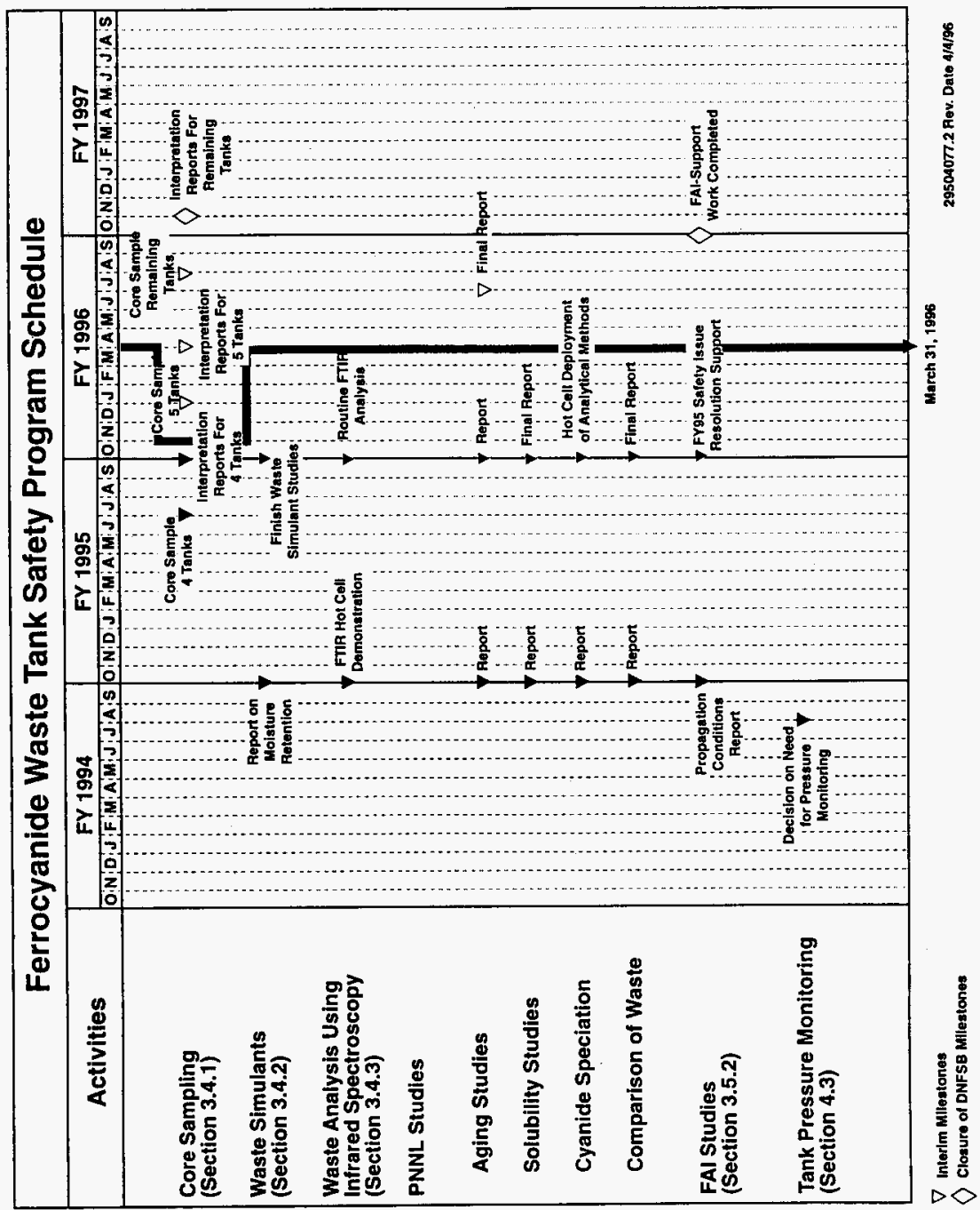


WHC-EP-0474-20

This page intentionally left blank. 


\subsection{REFERENCES}

Anttonen, J. H., 1993, Resolution of Unreviewed Safety Question (USQ) for Four Ferrocyanide Tanks, (letter 9304645B/93-CAB-223 to T. M. Anderson, President, Westinghouse Hanford Company, July 9), U.S. Department of Energy, Richland Operations Office, Richland, Washington.

Bacon, R. F., 1996a, Ferrocyanide Safety Program: Request for Resolution of the Ferrocyanide Safety Issue for Four C-Farm Tanks (Milestone T22-96-023), (letter 9650420 to J. D. Wagoner, DOE-RL, January 31), Westinghouse Hanford Company, Richland, Washington.

Bacon, R. F., 1996b, Ferrocyanide Safety Program: Request for Resolution of the Ferrocyanide Safery Issue and Deletion from the Watch List for Four C-Farm Tanks, (letter 9651198 to J. E. Kinzer, DOE-RL, March 19), Westinghouse Hanford Company, Richland, Washington.

Baldwin, J. H., R. J. Cash, W. I. Winters, L. Amato, and T. Tran, 1996a, Tank Characterization Report for Single-Shell Tank 241-BY-108, WHC-SD-WM-ER-533, Rev. 0, Westinghouse Hanford Company, Richland, Washington.

Baldwin, J. H., R. J. Cash, W. I. Winters, L. Amato, and T. Tran, 1996b, Tank Characterization Report for Single-Shell Tank 241-BY-108, WHC-SD-WM-ER-533, Rev. 0-A, Westinghouse Hanford Company, Richland, Washington. [March 25, 1996] \{ECN 629920\}

Bell, K. E., 1996, 45-Day Safety Screening Results for Tank 241-BY-106, Rotary Mode Core 121, WHC-SD-WM-DP-103, Rev. OB, Westinghouse Hanford Company, Richland, Washington.

Benar, C. J., 1996, 45-Day Safety Screening Results for Tank 241-BY-104, Rotary Mode [in Push Mode] Cores 116 and 117, WHC-SD-WM-DP-164, Rev. 0, Westinghouse Hanford Company, Richland, Washington.

Borsheim, G. L., and R. J. Cash, 1991, Unusual Occurrence - Addition of Two Tanks to List of Unreviewed Safety Question Tanks Containing Ferrocyanide, WHC-91-0096-TFARM, February 13, Westinghouse Hanford Company, Richland, Washington.

Borsheim, G. L., and B. C. Simpson, 1991, An Assessment of the Inventories of Ferrocyanide Watch List Tanks, WHC-SD-WM-EP-133, Rev. 0, Westinghouse Hanford Company, Richland, Washington. 
Bussell, J. H., 1992, Engineering Evaluation of Thermocouples in Ferrocyanide Watch List Tanks, WHC-SD-WM-ER-134, Rev. 0 and Rev. 0A, Westinghouse Hanford Company, Richland, Washington.

Cady, H. H., 1993, Evaluation of Ferrocyanide/Nitrate Explosive Hazard, LA-12589-MS, Los Alamos National Laboratory, Los Alamos, New Mexico.

Callaway, W. S., 1995, Scanning Electron Microscopic Analyses of Ferrocyanide Tank Wastes for the Ferrocyanide Safety Program - FY 1995 Report, WHC-SD-WM-RPT-194, Rev. 0, Westinghouse Hanford Company, Richland, Washington.

Cash, R. J., 1991, Implementation Plan for the Defense Nuclear Facilities Safety Board Recommendation 90-7, WHC-EP-0415, Rev. 0, Westinghouse Hanford Company, Richland, Washington.

Cash, R. J., and J. E. Meacham, 1996, Quarterly Report on the Ferrocyanide Safety Program for the Period Ending December 31, 1995, WHC-EP-0474-19, Westinghouse Hanford Company, Richland, Washington.

Cash, R. J., and J. M. Thurman, 1991, Action Plan for Response to Abnormal Conditions in Hanford Site Radioactive Waste Tanks Containing Ferrocyanide, EP-0407, Rev. 0, Westinghouse Hanford Company, Richland, Washington.

Cash, R. J., and J. M. Thurman, 1992, Action Plan for Response to Abnormal Conditions in Hanford Site Radioactive Waste Tanks Containing Ferrocyanide, EP-0407, Rev. 1, Westinghouse Hanford Company, Richland, Washington.

Claybrook, S. W., and S. A. Wood, 1994, Organic Evaporation in Waste Tank C-103, WHC-SD-WM-ER-344, Rev. 0, Westinghouse Hanford Company, Richland, Washington.

Crowe, R. D., M. Kummerer, and A. K. Postma, 1993, Estimation of Heat Load in Waste Tanks Using Average Vapor Space Temperatures, WHC-EP-0709, Rev. 0, Westinghouse Hanford Company, Richland, Washington.

Deaton, D. E., 1990, Unusual Occurrence - Unreviewed Safety Questions Regarding Tanks Containing Ferrocyanide, WHC-90-B003-R1 (Update 10-22-90), Westinghouse Hanford Company, Richland, Washington.

Dickinson, D. R., J. M. McLaren, G. L. Borsheim, and M. D. Crippen, 1993, Ferrocyanide Safety Program: Credibility of Drying Out Ferrocyanide Tank Waste by Hot Spots, WHC-EP-0648, Rev. 0, Westinghouse Hanford Company, Richland, Washington. 
DOE, 1987, Final Environmental Impact Statement, Disposal of Hanford Defense High-Level, Transuranic and Tank Waste, Hanford Site, Richland, Washington, DOE/EIS-0113, Vol. 1 through 5, U.S. Department of Energy, Washington, D.C.

DOE, 1994a, Recommendation 93-5 Implementation Plan, DOE/RL 94-0001, U.S. Department of Energy, Richland Operations Office, Richland, Washington.

DOE, 1994b, Program Plan for Resolution of the Ferrocyanide Waste Tank Safety Issue at the Hanford Site, DOE/RL-94-110, Rev. 1, U.S. Department of Energy, Richland Operations Office, Richland, Washington.

Douglas, J. G., and F. R. Reich, 1995, Summary Report of FY 1995 Raman Spectroscopy Technology Development, WHC-SD-TD-TI-003, Rev. 0, Westinghouse Hanford Company, Richland, Washington.

Epstein, M., H. K. Fauske, M. D. Crippen, D. R. Dickinson, J. D. McCormack, R. J. Cash, J. E. Meacham, and C. S. Simmons, 1994, Ferrocyanide Safety Program: An Assessment of the Possibility of Ferrocyanide Sludge Dryout, WHC-EP-0816, Rev. 0, Westinghouse Hanford Company, Richland, Washington.

Fauske, H. K., 1996, Assessment of Chemical Vulnerabilities in the Hanford High-Level Waste Tanks, WHC-SD-WM-ER-543, Rev. 0, Westinghouse Hanford Company, Richland, Washington.

FR, 1990, "Implementation Plan for Recommendation 90-3 at the Department of Energy's Hanford Site, Washington, " Federal Register, Defense Nuclear Facilities Safety Board Recommendation 90-7, Vol. 55, No. 202, pp. 42243 - 42244.

Finfrock, S. H., H. Toffer, and W. T. Watson, 1994, Potential Tank Waste Material Anomalies Located Near the Liquid Observation Wells: Model Predicted Responses of a Neutron Moisture Detection System, WHC-EP-0809, Westinghouse Hanford Company, Richland, Washington.

Fowler, K. D., 1994, Action Plan for Response to Abnormal Conditions in Hanford Site Radioactive Waste Tanks Containing Ferrocyanide, WHC-EP-0407, Rev. 2, Westinghouse Hanford Company, Richland, Washington.

Fowler, K. D., and R. D. Graves, 1994, Decision Analysis for Continuous Cover Gas Monitoring of Ferrocyanide Watch List Tanks, WHC-EP-0743, Rev. 0, Westinghouse Hanford Company, Richland, Washington. 
Gerton, R. E., 1994, Environmental Assessment (EA) and Finding of No Significant Impact (FONSI) for the Waste Tank Safety Program at the Hanford Site, (DOE/EA-0915), (letter 9402034B/94-SST-053 to President, Westinghouse Hanford Company, March 8), U.S. Department of Energy, Richland, Washington.

Grigsby, J. M., A. K. Postma, R. J. Cash, J. E. Meacham, M. A. Lilga, H. K. Fauske, and M. Epstein, 1996a, Assessment of the Potential for Ferrocyanide Propagating Reaction Accidents, WHC-SD-WM-SARR-038, Rev. 0, Westinghouse Hanford Company, Richland, Washington.

Grigsby, J. M., A. K. Postma, R. J. Cash, J. E. Meacham, M. A. Lilga, H. K. Fauske, and M. Epstein, 1996b, Assessment of the Potential for Ferrocyanide Propagating Reaction Accidents, WHC-SD-WM-SARR-038, Rev. 0A, Westinghouse Hanford Company, Richland, Washington.

Grigsby, J. M., D. B. Bechtold, G. L. Borsheim, M. D. Crippen, D. R. Dickinson, G. L. Fox, D. W. Jeppson, M. Kummerer, J. M. McLaren, J. D. McCormack, A. Padilla, B. C. Simpson, and D. D. Stepnewski, 1992, Ferrocyanide Waste Tank Hazard Assessment--Interim Report, WHC-SD-WM-RPT-032, Rev. 1, Westinghouse Hanford Company, Richland, Washington.

Guimond, R. J., 1996, [Closure of Defense Nuclear Facilities Safety Board Recommendation 90-7], (letter to J. T. Conway, Chairman, DNFSB, March 13), U.S. Department of Energy, Washington, D.C.

Harmon, H. D., 1991, Safety Measures for Waste Tanks at Hanford Site, Richland, Washington, (letter 9059124.1 to R. E. Gerton, DOE-RL, February 8), Westinghouse Hanford Company, Richland, Washington.

Jeppson, D. W., and J. J. Wong, 1993, Ferrocyanide Waste Simulant Characterization, WHC-EP-0631, Westinghouse Hanford Company, Richland, Washington.

Kelly, S. E., 1995a, Tank Characterization Report for Single Shell Tank 241-C-111, WHC-SD-WM-ER-475, Rev. 0-B, Westinghouse Hanford Company, Richland, Washington.

Kelly, S. E., 1995b, Tank Characterization Report for Single Shell Tank 241-TY-104, WHC-SD-WM-ER-481, Rev. 0-A, Westinghouse Hanford Company, Richland, Washington. 
Kress, T., K. Bandyopadhyay, P. d'Entremont, S. Slezak, and M. Reich, 1990, Risk of a Ferrocyanide Explosion in the Hanford Waste Tank Farm, (memorandum to John Tseng, DOE-HQ, September 20), Ad Hoc Task Force formed by U.S. Department of Energy to evaluate the ferrocyanide safety concerns at the Hanford Site, Oak Ridge National Laboratory, Oak Ridge, Tennessee.

Lipke, E. J., 1995, Ferrocyanide Safety Program: Completion of Milestone Report on Tank Moisture Data Interpretation Computer Program, (letter 9554603 to R. E. Gerton, DOE-RL, August 30), Westinghouse Hanford Company, Richland, Washington.

McLaren, J. M., 1993, Ferrocyanide Safety Program: Updated Thermal Analysis Model for Ferrocyanide Tanks with Application to Tank 241-BY-104, WHC-EP-0669, Rev. 0, Westinghouse Hanford Company, Richland Washington.

McLaren, J. M., 1994a, Ferrocyanide Safety Program: Thermal Analysis of Ferrocyanide Tanks, Group I, WHC-EP-0729, Rev. 0, Westinghouse Hanford Company, Richland, Washington.

McLaren, J. M., 1994b, Ferrocyanide Safety Program: Thermal Analysis of Ferrocyanide Watch List Tanks, Group II, WHC-EP-0794, Rev. 0, Westinghouse Hanford Company, Richland, Washington.

Meacham, J. E., H. Babad, and H. Toffer, 1993, Moisture Monitoring of Ferrocyanide Tanks: An Evaluation of Methods and Tools, WHC-EP-0658, Rev. 0, Westinghouse Hanford Company, Richland, Washington.

Meacham, J. E., R. J. Cash, B. A. Pulsipher, and G. Chen, 1995, Data Requirements for the Ferrocyanide Safety Issue Developed Through the Data Quality Objectives Process, WHC-SD-WM-DQO-007, Rev. 1, Westinghouse Hanford Company, Richland, Washington.

Nguyen, D. M., 1989, Data Analysis of Conditions in Single-Shell Tanks Suspected of Containing Ferrocyanide, (internal memorandum 13314-89-025 to N. W. Kirch, March 2), Westinghouse Hanford Company, Richland, Washington.

O'Leary, H. R., 1994, [Transmittal of "Program Plan for Evaluation of the Ferrocyanide Waste Tank Safety issue at the Hanford Site, " DOE/RL-94-110], (letter to J. T. Conway, Chairman, Defense Nuclear Facilities Safety Board, December 2), U.S. Department of Energy, Washington, D.C.

Payne, M. A., 1994a, Ferrocyanide Safety Program: Transmittal of General Accounting Office Closeout Report, (letter 9454280 to R. E. Gerton, DOE-RL, June 16), Westinghouse Hanford Company, Richland, Washington. 
Payne, M. A., 1994b, Ferrocyanide Safety Program: Continuous Pressure Monitoring in Ferrocyanide Watch List Tanks, (letter 9455175 to R. E. Gerton, DOE-RL, July 29), Westinghouse Hanford Company, Richland, Washington.

Peach, J. D., 1990, Consequences of Explosion of Hanford's Single-Shell Tanks are Understated, (letter B-241479 to M. Synar, Chairman, Environment, Energy, and Natural Resources Subcommittee, Committee on Government Operations, House of Representatives, October 10), GAO/RCED-91-34, U.S. General Accounting Office, Washington, D.C.

Postma, A. K., J. E. Meacham, G. S. Barney, G. L. Borsheim, R. J. Cash, M. D. Crippen, D. R. Dickinson, J. M. Grigsby, D. W. Jeppson, M. Kummerer, J. M. McLaren, C. S. Simmons, and B. C. Simpson, 1994a, Ferrocyanide Safety Program: Safety Criteria for Ferrocyanide Watch List Tanks, WHC-EP-0691, Westinghouse Hanford Company, Richland, Washington.

Postma, A. K., D. B. Bechtold, G. L. Borsheim, J. M. Grigsby, R. L. Guthrie, M. Kummerer, M. G. Plys, and D. A. Turner, 1994b, Safety Analysis of Exothermic Reaction Hazards Associated with the Organic Liquid Layer in Tank 241-C-103, WHC-SD-WM-SARR-001, Rev. 0, Westinghouse Hanford Company, Richland, Washington.

Public Law 101-510, Section 3137, 1990, Safety Measures for Waste Tanks at Hanford Nuclear Reservation, U.S. Congress, Washington, D.C. [Also referred to as the Wyden Amendment]

Rebagay, T. V., R. J. Cash, D. A. Dodd, C. T. Narquis, F. R. Reich, and W. D. Winkelman, 1995, Remote Characterization of Mixed Waste by Fourier Transform Infrared Spectroscopy, WHC-SD-WM-RPT-192, Rev. 0, Westinghouse Hanford Company, Richland, Washington.

Reich, F. R., R. E. Johnson, B. L. Philipp, J. B. Duncan, and G. L. Schutzenhofer, 1994, Summary of Fiscal Year 1994 Near-Infrared Spectroscopy Moisture Sensing Activities, WHC-EP-0839, Westinghouse Hanford Company, Richland, Washington.

Reich, F. R., T. V. Rebagay, D. A. Dodd, T. Lopez, and J. K. Watts, 1995, Summary of FY 1995 NIR Moisture Measurement Development and Implementation Activities, WHC-SD-WM-RPT-191, Rev. 0, Westinghouse Hanford Company, Richland, Washington.

Riedel, E. F., 1995, Ferrocyanide Safety Program: FY 1995 Report on Mössbauer Spectroscopy Task Activities, WHC-SD-WM-RPT-195, Rev. 0, Westinghouse Hanford Company, Richland, Washington. 
Sasaki, L. M., 1995, Tank Characterization Report for Single Shell Tank 241-C-108, WHC-SD-WM-ER-503, Rev. 0, Westinghouse Hanford Company, Richland, Washington.

Sasaki, L. M., 1996, 45-Day Safety Screening Results for Tank 241-BY-105, Rotary and Push Mode Core 108, WHC-SD-WM-DP-162, Rev. 0, Westinghouse Hanford Company, Richland, Washington.

Sheridan, T. R., 1994a, Closure of the Ferrocyanide Unreviewed Safety Question, (letter 9401180/94-SST-052 to A. L. Trego, President, Westinghouse Hanford Company, March 4), U.S. Department of Energy, Richland Operations Office, Richland, Washington.

Sheridan, T. R., 1994b, Approval to Remove Two Ferrocyanide Tanks, 241-BX-102 and 241-BX-106, from the Watch List, (letter 9406684/94-SST-205 to A. L. Trego, President, Westinghouse Hanford Company, November 17), U.S. Department of Energy, Richland Operations Office, Richland, Washington.

Simmons, C. S., 1995, Modeling Water Retention of Tank Waste, PNL-10831, Pacific Northwest Laboratory, Richland, Washington.

Sloat, R. J., 1954, TBP Plant Nickel Ferrocyanide Scavenging Flowsheet, HW-30399, General Electric Company, Richland, Washington.

Sloat, R. J., 1955, In-Farm Scavenging Operating Procedure and Control Data, HW-38955, General electric Company, Richland, Washington.

Smith, D. A., 1986, Single-Shell Tank Isolation Safety Analysis Report, SD-WM-SAR-006, Rev. 2, Westinghouse Hanford Company, Richland, Washington.

Trine, S. L., 1996, Document Provided to Defense Nuclear Facilities Safety Board (DNFSB), (letter 96-PAD-079 to R. Tontodonato, DNFSB, April 10), U.S. Department of Energy, Richland Operations Office, Richland, Washington.

Wagoner, J. D., 1993, Approval of Hanford Site Tank Farm Facilities Interim Safety Basis, (letter 93-TOB-209 to T. M. Anderson, President, Westinghouse Hanford Company, November 18), U.S. Department of Energy, Richland Operations Office, Richland, Washington.

Watkins, J. D., 1991, Report to United States Congress on Waste Tank Safety Issues at the Hanford Site, (letter to D. Quayle, President of the Senate, July 16), U.S. Department of Energy, Washington, D.C. 
Watson, W. T., 1993, Proof of Principle Report for In-Tank Moisture Monitoring Using an Active Neutron Probe, WHC-EP-0695, Westinghouse Hanford Company, Richland, Washington.

WHC, 1990, Operating Specifications for Watch List Tanks, OSD-T-151-00030, Rev. 0, Westinghouse Hanford Company, Richland, Washington.

WHC, 1991, Tank Farm Stabilization Plan for Emergency Response, WHC-SD-PRP-TI-001, Rev. 0, Westinghouse Hanford Company, Richland, Washington.

WHC, 1996, Operating Specifications for Watch List Tanks, OSD-T-151-00030, Rev. B-16, Westinghouse Hanford Company, Richland, Washington.

Wood, S. A., 1992, Gas Space Analysis For Tank C-109, WHC-SD-WM-ER-183, Rev. 0, Westinghouse Hanford Company, Richland, Washington. 
APPENDIX A

FERROCYANIDE TANK INFORMATION SUMMARY

A-1 
This page intentionally left blank. 
Table A-1. Summary of Contents and Status of Ferrocyanide Tanks.

\begin{tabular}{|c|c|c|c|c|c|c|}
\hline Tank & $\begin{array}{c}\text { Total waste } \\
\text { volume } \\
(1,000 \mathrm{~L})\end{array}$ & $\begin{array}{c}\mathrm{FeCN}^{\mathrm{b}} \\
(1,000 \mathrm{~g} \text {-mole })\end{array}$ & $\begin{array}{c}\text { Heat load } \\
(\mathrm{kW})^{\mathrm{c}}\end{array}$ & $\begin{array}{l}\text { Maximum } \\
\text { temp. } \\
\left({ }^{\circ} \mathrm{C}\right) \quad\left({ }^{\circ} \mathrm{F}\right)\end{array}$ & Riser No. & $\begin{array}{l}\text { Status of } \\
\text { tanks }^{d}\end{array}$ \\
\hline BY-103 & 1510 & 66 & 1.6 & $\begin{array}{ll}27 & 80 \\
26^{\circ} & 79\end{array}$ & $\begin{array}{l}1 \\
5\end{array}$ & NS; AL \\
\hline BY-104 & 1540 & 83 & $3.3^{f}$ & $\begin{array}{ll}52^{\mathrm{c}} & 125 \\
44 & 112\end{array}$ & $\begin{array}{c}1 \\
10 B\end{array}$ & IS; Sound \\
\hline BY-105 & 1900 & 36 & $4.9^{f}$ & $\begin{array}{ll}47 & 116 \\
44 & 111\end{array}$ & $\begin{array}{c}1 \\
10 \mathrm{C}\end{array}$ & NS; AL \\
\hline BY-106 & 2430 & 70 & $4.7^{f}$ & $50 \quad 123$ & 1 & NS; AL \\
\hline BY-107 & 1010 & 42 & 2.6 & $\begin{array}{ll}35 & 95 \\
37^{\mathrm{e}} & 99\end{array}$ & $\begin{array}{l}1 \\
5\end{array}$ & IS; AL \\
\hline BY-108 & 863 & 58 & 2.7 & $\begin{array}{ll}42^{\circ} & 108 \\
42 & 107\end{array}$ & $\begin{array}{l}3 \\
8\end{array}$ & IS; AL \\
\hline BY-110 & 1510 & 71 & $3.3^{f}$ & $\begin{array}{ll}47 & 117 \\
41^{e} & 106\end{array}$ & $\begin{array}{c}1 \\
10 \mathrm{~A}\end{array}$ & IS; Sound \\
\hline BY-111 & 1690 & 6 & $2.1^{f}$ & $\begin{array}{ll}31^{8} & 87 \\
29^{c} & 84\end{array}$ & $\begin{array}{c}1 \text { (LOW) } \\
14\end{array}$ & IS; Sound \\
\hline BY-112 & 1100 & 2 & $2.4^{f}$ & $\begin{array}{ll}32^{\mathrm{c}} & 90 \\
29^{\mathrm{g}} & 84\end{array}$ & $\begin{array}{c}2 \\
15 \text { (LOW) }\end{array}$ & IS; Sound \\
\hline C-108 & 250 & 25 & $2.9^{f}$ & $\begin{array}{ll}25^{c} & 76 \\
23 & 74\end{array}$ & $\begin{array}{l}1 \\
5\end{array}$ & IS; Sound \\
\hline C-109 & 250 & $6.8^{\mathrm{h}}$ & $3.0^{f}$ & $\begin{array}{ll}27^{e} & 80 \\
26 & 79\end{array}$ & $\begin{array}{l}3 \\
8\end{array}$ & IS; Sound \\
\hline$C-111$ & 216 & 33 & $2.5^{f}$ & $\begin{array}{ll}24 & 75 \\
23^{\text {e }} & 74\end{array}$ & $\begin{array}{l}5 \\
6\end{array}$ & IS; AL \\
\hline C-112 & 394 & $11.5^{\mathrm{h}}$ & $3.3^{f}$ & $\begin{array}{ll}28 & 83 \\
28^{e} & 82\end{array}$ & $\begin{array}{l}1 \\
8\end{array}$ & IS; Sound \\
\hline $\mathrm{T}-107$ & 681 & 5 & $1.2^{f}$ & $\begin{array}{ll}19 & 65 \\
19^{c} & 66\end{array}$ & $\begin{array}{l}4 \\
5\end{array}$ & NS; AL \\
\hline TX-118 & 1310 & $<3$ & 1.4 & $\begin{array}{ll}25^{e} & 78 \\
25 & 76\end{array}$ & $\begin{array}{l}1 \\
3\end{array}$ & IS; Sound \\
\hline TY-101 & 447 & 23 & $1.1^{f}$ & $\begin{array}{ll}19^{c} & 65 \\
19 & 65\end{array}$ & $\begin{array}{l}3 \\
4\end{array}$ & $\mathrm{IS} ; \mathrm{AL}$ \\
\hline
\end{tabular}


Table A-1. Summary of Contents and Status of Ferrocyanide Tanks. ${ }^{2}$

\begin{tabular}{|c|c|c|c|c|c|c|}
\hline Tank & $\begin{array}{c}\text { Total waste } \\
\text { volume } \\
(1,000 \mathrm{~L})\end{array}$ & $\begin{array}{c}\mathrm{FeCN}^{\mathrm{b}} \\
(1,000 \mathrm{~g} \text {-mole })\end{array}$ & $\begin{array}{l}\text { Heat load } \\
\qquad(\mathrm{kW})^{\mathrm{c}}\end{array}$ & $\begin{array}{l}\text { Maximum } \\
\text { temp. } \\
\left({ }^{\circ} \mathrm{C}\right) \quad\left({ }^{\circ} \mathrm{F}\right)\end{array}$ & Riser No. & $\begin{array}{l}\text { Status of } \\
\text { tanks }\end{array}$ \\
\hline TY-103 & 613 & 28 & 1.5 & $\begin{array}{ll}21 & 69 \\
21^{e} & 70\end{array}$ & $\begin{array}{l}4 \\
7\end{array}$ & IS; $\mathrm{AL}$ \\
\hline TY-104 & 174 & 12 & 0.9 & $\begin{array}{ll}18^{e} & 65 \\
18 & 64\end{array}$ & $\begin{array}{l}3 \\
4\end{array}$ & $\mathrm{IS} ; \overline{\mathrm{AL}}$ \\
\hline
\end{tabular}

Notes:

a Reflects removal of four ferrocyanide tanks from the Watch List in July 1993 and two additional tanks in October 1994. Tank information as of March 1996; temperatures are highest recorded during the last quarter ending March 31, 1996.

b Original tank inventories (Borsheim and Simpson 1991).

c Heat load values from Table 7-1 in Crowe et al. (1993).

d IS - Interim Stabilized Tank; NS - Not Stabilized; AL - Assumed Leaker Tank; Sound - Non-Leaking Tank.

- Readings from new instrument trees; tank 241-BY-105 already had two trees.

f New data taken from Crowe et al. (1995).

s Temperature reading from a single thermocouple in the LOW.

${ }^{h}$ Calculated as ferrocyanide $\left[\mathrm{Fe}(\mathrm{CN})_{6}^{-4}\right]$ based on the total cyanide values reported in Simpson et al. (1993a, 1993b). 
Table A-2. Ferrocyanide Tank Vapor Sampling Summary. (2 Sheets)

\begin{tabular}{|c|c|c|c|c|c|c|c|c|c|c|c|c|c|}
\hline Tank & $\begin{array}{c}\text { Date } \\
\text { Sampled } \\
\text { (Type)" }\end{array}$ & $\begin{array}{l}\text { Flamm. } \\
(\% \text { LEL })^{b}\end{array}$ & $\begin{array}{l}\text { Organic } \\
\text { Vapor } \\
\text { (ppmv) }^{c}\end{array}$ & $\begin{array}{c}\mathrm{NH}_{3} \\
(\mathrm{ppmv})^{\mathrm{d}}\end{array}$ & $\begin{array}{c}\mathrm{NH}_{3} \\
(\mathrm{ppmv})^{c}\end{array}$ & $\begin{array}{c}\mathrm{HCN} \\
(\text { ppmv) }\end{array}$ & $\begin{array}{l}\mathrm{NO}+\mathrm{NO}_{2} \\
(\mathrm{ppmv})^{d},\end{array}$ & $\begin{array}{l}\text { TNMOC } \\
\left(\mathrm{mg} / \mathrm{m}^{3}\right)^{\mathrm{f}}\end{array}$ & $\begin{array}{c}\mathrm{H}_{2} \\
(\mathrm{ppmv})^{\mathrm{t}}\end{array}$ & $\begin{array}{c}\mathrm{N}_{2} \mathrm{O} \\
(\text { ppmv)t }\end{array}$ & $\begin{array}{c}\mathrm{CO} \\
\text { (ppmv)t }\end{array}$ & $\begin{array}{c}\mathrm{CO}_{2} \\
\text { (ppmv) }\end{array}$ & $\begin{array}{c}\text { Water } \\
\text { Content } \\
\% \text { RH }\left({ }^{\circ} \mathrm{C}\right)^{h}\end{array}$ \\
\hline$\overline{\mathrm{BY}-103}$ & $\begin{array}{l}05 / 05 / 94(2) \\
11 / 01 / 94(3)\end{array}$ & $\begin{array}{c}<1 \\
-j\end{array}$ & $\begin{array}{l}1.2 \\
--\end{array}$ & $\begin{array}{r}25 \\
--\end{array}$ & $\begin{array}{l}30.7 \\
26\end{array}$ & $\begin{array}{c}<0.005^{\prime} \\
-\end{array}$ & $\begin{array}{l}<0.3 \\
<0.2\end{array}$ & $\begin{array}{l}5.2 \\
-\end{array}$ & $\begin{array}{l}21.4 \\
<99\end{array}$ & $\begin{array}{l}49.2 \\
16.5\end{array}$ & $\begin{array}{r}<1 \\
<12\end{array}$ & $12 \overline{126}$ & $49\left(25.5^{\circ} \mathrm{C}\right)$ \\
\hline BY-104 & $\begin{array}{l}04 / 22 / 94(2) \\
06 / 24 / 94(3)\end{array}$ & $\begin{array}{r}<1 \\
--\end{array}$ & 26 & $\begin{array}{r}200 \\
-\end{array}$ & $\begin{array}{l}285 \\
248\end{array}$ & $\begin{array}{c}<0.005^{\prime} \\
--\end{array}$ & $\begin{array}{l}<0.3 \\
<0.4\end{array}$ & $\begin{array}{l}56 \\
61 \\
\end{array}$ & $\begin{array}{l}204 \\
295\end{array}$ & $\begin{array}{l}305 \\
201\end{array}$ & $\begin{array}{r}<1 \\
1\end{array}$ & $\overline{10.5}$ & $58\left(26^{\circ} \mathrm{C}\right)$ \\
\hline $\mathrm{BY}-105$ & $\begin{array}{l}05 / 09 / 94(2) \\
07 / 07 / 94(3)\end{array}$ & $\begin{array}{r}<1 \\
-\end{array}$ & $\begin{array}{l}4.9 \\
--\end{array}$ & $\begin{array}{l}40 \\
-\end{array}$ & $\begin{array}{l}57 \\
43\end{array}$ & $\begin{array}{c}<0.005^{i} \\
-\end{array}$ & $\begin{array}{l}<0.1 \\
<0.2\end{array}$ & $\begin{array}{l}17.8 \\
12.7 \\
\end{array}$ & $\begin{array}{l}8 \overline{5} \\
48\end{array}$ & $\begin{array}{r}122 \\
50\end{array}$ & $\begin{array}{l}0.5 \\
0.4\end{array}$ & 94 & $61\left(26^{\circ} \mathrm{C}\right)$ \\
\hline $\mathrm{BY}-106$ & $\begin{array}{l}05 / 04 / 94(2) \\
07 / 08 / 94(3)\end{array}$ & $\begin{array}{r}<1 \\
--\end{array}$ & $\begin{array}{l}5.7 \\
--\end{array}$ & $\begin{array}{r}60 \\
--\end{array}$ & $\begin{array}{l}87 \\
74\end{array}$ & $<0.01-$ & $\begin{array}{l}<0.2 \\
<0.2\end{array}$ & $\begin{array}{l}6.3 \\
9.9\end{array}$ & $\begin{array}{l}46 \\
46\end{array}$ & $\begin{array}{l}94 \\
71\end{array}$ & $\overline{0.5}$ & $\begin{array}{l}- \\
47.6\end{array}$ & $57\left(27^{\circ} \mathrm{C}\right)$ \\
\hline BY-107 & $\begin{array}{l}03 / 25 / 94(2) \\
10 / 26 / 94(3)\end{array}$ & $\begin{array}{c}3-4 \\
-\end{array}$ & $\begin{array}{c}67 \\
--\end{array}$ & $\begin{array}{r}97 \\
-\end{array}$ & 972 & $\cdots$ & $<0.2$ & $\begin{array}{l}173 \\
150 \\
\end{array}$ & $\begin{array}{l}692 \\
267\end{array}$ & $\begin{array}{l}802 \\
621\end{array}$ & $\begin{array}{r}<5 \\
<20 \\
\end{array}$ & $\overline{94}$ & $36\left(33.1^{\circ} \mathrm{C}\right)$ \\
\hline BY-108 & $\begin{array}{l}03 / 28 / 94(2) \\
10 / 27 / 94 \text { (3) }\end{array}$ & $\begin{array}{c}1 \\
-\pi\end{array}$ & $\begin{array}{l}97 \\
--\end{array}$ & $\begin{array}{r}700 \\
--\end{array}$ & 1040 & - & $\begin{array}{l}<0.5 \\
<0.1\end{array}$ & $\begin{array}{l}594 \\
510\end{array}$ & $\begin{array}{l}644 \\
400\end{array}$ & $\begin{array}{l}757 \\
641\end{array}$ & $\begin{array}{r}<5 \\
<76 \\
\end{array}$ & 224 & $56\left(25.7^{\circ} \mathrm{C}\right)$ \\
\hline$\overline{B Y}-110$ & $\begin{array}{l}09 / 27 / 92(1) \\
11 / 11 / 94(3)\end{array}$ & $\begin{array}{r}<1 \\
--\end{array}$ & $\begin{array}{r}350 \\
-\end{array}$ & $\begin{array}{r}612 \\
-\end{array}$ & $\begin{array}{r}-- \\
401\end{array}$ & $\begin{array}{l}<\overline{2} \\
-\end{array}$ & $\begin{array}{l}<0.5 \\
<0.2\end{array}$ & 29 & $\begin{array}{r}-- \\
<160\end{array}$ & 103 & $<\overline{-}$ & $\begin{array}{r}-- \\
229\end{array}$ & $31\left(27^{\circ} \mathrm{C}\right)$ \\
\hline BY-111 & $\begin{array}{l}05 / 11 / 94(2) \\
11 / 16 / 94(3)\end{array}$ & $\begin{array}{r}<1 \\
--\end{array}$ & 8.9 & $\begin{array}{c}60 \\
\cdots\end{array}$ & $\overline{59}$ & 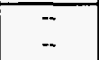 & $<\overline{0.2}$ & 9.6 & $\overline{67}$ & 99 & $\begin{array}{l}<1 \\
<1\end{array}$ & $\begin{array}{r}-+ \\
219\end{array}$ & $27\left(27^{\circ} \mathrm{C}\right)$ \\
\hline $\mathrm{BY}-112$ & $\begin{array}{l}03 / 26 / 93(1) \\
11 / 18 / 94(3)\end{array}$ & $\begin{array}{r}<1 \\
--\end{array}$ & $\begin{array}{l}5.9 \\
--\end{array}$ & $\begin{array}{l}10 \\
-- \\
\end{array}$ & $\overline{63}$ & $\begin{array}{l}<2 \\
-\end{array}$ & $\begin{array}{l}<0.5 \\
<0.2\end{array}$ & 5.8 & $<94$ & 40 & $<\overline{12}$ & $12 \overline{1}$ & $53\left(23.3^{\circ} \mathrm{C}\right)$ \\
\hline C-108 & $\begin{array}{c}07 / 23 / 93\left({ }^{* *}\right) \\
07 / 07 / 94(2) \\
08 / 05 / 94(3)\end{array}$ & $\begin{array}{r}<1 \\
- \\
-\end{array}$ & $\begin{array}{l}1.2 \\
-- \\
-\end{array}$ & $\begin{array}{r}<2 \\
-- \\
--\end{array}$ & $\begin{array}{l}- \\
- \\
2.7\end{array}$ & $\begin{array}{c}<2 \\
<0.0002^{i} \\
\ldots\end{array}$ & $\begin{array}{c}<\overline{0} .5 \\
-\overline{<0.3}\end{array}$ & $\begin{array}{l}-\overline{-} \\
<0.4 \\
<1.4\end{array}$ & $\overline{\overline{15.3}}$ & $\begin{array}{r}-- \\
-- \\
344\end{array}$ & $\begin{array}{l}1 \\
- \\
0.1\end{array}$ & $\begin{array}{l}-- \\
-- \\
16.3\end{array}$ & $\begin{array}{c}-- \\
-\overline{-} \\
76\left(25^{\circ} \mathrm{C}\right)\end{array}$ \\
\hline $\mathrm{C}-109$ & $\begin{array}{l}06 / 23 / 94(2) \\
08 / 09 / 94(3)\end{array}$ & $\begin{array}{r}<1 \\
--\end{array}$ & $\begin{array}{c} \\
--\end{array}$ & $\begin{array}{c}4 \\
--\end{array}$ & $\overline{10.1}$ & $\cdots$ & $<\overline{0.6}$ & 0.65 & 125 & 369 & $\overline{0.4}$ & -- & $79\left(27^{\circ} \mathrm{C}\right)$ \\
\hline C-111 & $\begin{array}{l}08 / 10 / 93(* *) \\
06 / 20 / 94 \text { (2) } \\
09 / 13 / 94(3)\end{array}$ & $\begin{array}{r}<1 \\
<1 \\
-\end{array}$ & $\begin{array}{c}<0.2 \\
<0.2 \\
-\end{array}$ & $\begin{array}{l}<2 \\
<2 \\
-\end{array}$ & $\begin{array}{l}- \\
0.1 \\
5.6\end{array}$ & $\begin{array}{c}<0.04^{k} \\
<0.01^{i} \\
\ldots\end{array}$ & $\begin{array}{l}<0.5 \\
<0.2 \\
\leq 0.7\end{array}$ & $\begin{array}{c}<0.3 \\
0.18 \\
<0.6\end{array}$ & $\begin{array}{c}16 \\
-- \\
12.4\end{array}$ & $\begin{array}{c}39 \\
-- \\
99\end{array}$ & $\begin{array}{l}0.1 \\
- \\
0.1\end{array}$ & $\begin{array}{r}-- \\
-- \\
198\end{array}$ & $86\left(27^{\circ} \mathrm{C}\right)$ \\
\hline C-112 & $\begin{array}{l}06 / 24 / 94(2) \\
08 / 11 / 94(3)\end{array}$ & $\begin{array}{r}<1 \\
-.\end{array}$ & $\begin{array}{c}<0.2 \\
--\end{array}$ & $\begin{array}{l}4 \\
--\end{array}$ & 22.7 & - & $<0.7$ & $\overline{3.4}$ & 204 & 544 & 0.9 & $\overline{102}$ & $82\left(28^{\circ} \mathrm{C}\right)$ \\
\hline T-107 & $\begin{array}{l}10 / 22 / 92(1) \\
01 / 18 / 95(3)\end{array}$ & $\begin{array}{r}<1 \\
--\end{array}$ & $\begin{array}{r}24 \\
-\end{array}$ & $\begin{array}{r}203 \\
-- \\
\end{array}$ & $12 \overline{-}$ & $\begin{array}{l}<2 \\
--\end{array}$ & $\begin{array}{l}<0.5 \\
<0.1\end{array}$ & $\overline{1.4}$ & $<\overline{94}$ & 42 & $<\overline{12}$ & $\overline{75}$ & $82\left(17.2^{\circ} \mathrm{C}\right)$ \\
\hline
\end{tabular}


Table A-2. Ferrocyanide Tank Vapor Sampling Summary. (2 Sheets)

\begin{tabular}{|c|c|c|c|c|c|c|c|c|c|c|c|c|c|}
\hline Tank & $\begin{array}{c}\text { Date } \\
\text { Sampled } \\
\text { (Type)" }\end{array}$ & 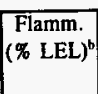 & $\begin{array}{c}\text { Organic } \\
\text { Vapor } \\
\text { (ppmv) }\end{array}$ & $\begin{array}{c}\mathrm{NH}_{3} \\
(\mathrm{ppmv})^{\mathrm{o}}\end{array}$ & $\begin{array}{c}\mathrm{NH}_{3} \\
(\mathrm{ppmv})^{\mathrm{e}}\end{array}$ & $\begin{array}{c}\mathrm{HCN} \\
(\mathrm{ppmv})^{\mathrm{d}}\end{array}$ & $\begin{array}{l}\mathrm{NO}+\mathrm{NO}_{2} \\
(\mathrm{ppmv})^{\mathrm{d}},{ }^{\prime}\end{array}$ & $\begin{array}{l}\text { TNMOC } \\
\left(\mathrm{mg} / \mathrm{m}^{3}\right)^{\mathrm{r}}\end{array}$ & $\frac{\begin{array}{c}\mathrm{H}_{2} \\
(\mathrm{ppmv})^{\prime}\end{array}}{}$ & $\begin{array}{c}\mathrm{N}_{2} \mathrm{O} \\
(\mathrm{ppmv})^{2}\end{array}$ & $\begin{array}{c}\mathrm{CO} \\
(\mathrm{ppmv})^{2}\end{array}$ & $\begin{array}{c}\mathrm{CO}_{2} \\
(\mathrm{ppmv})^{\prime}\end{array}$ & $\begin{array}{c}\text { Water } \\
\text { Content } \\
\text { \%RH }\left({ }^{\circ} \mathrm{C}\right)^{\mathrm{n}}\end{array}$ \\
\hline TX-118 & $\begin{array}{l}07 / 28 / 93\left(^{(* *}\right) \\
09 / 07 / 94(2) \\
12 / 16 / 94(3)\end{array}$ & $\begin{array}{l}<1 \\
<1 \\
--\end{array}$ & $\begin{array}{l}0.3 \\
7.8 \\
-\end{array}$ & $\begin{array}{l}10 \\
28 \\
-\end{array}$ & $\overline{-}$ & $\begin{array}{l}<2 \\
<0.02 \\
--\end{array}$ & $\begin{array}{l}<0.5 \\
<0.5 \\
--\end{array}$ & $\overline{-} .3$ & $\begin{array}{r}\ddot{-} \\
97 \\
<94\end{array}$ & $\begin{array}{l}\overline{17} \\
29\end{array}$ & $\begin{array}{l}\overline{2.5} \\
<12\end{array}$ & $\begin{array}{l}- \\
54 \\
98\end{array}$ & $\begin{array}{c}-\overline{-} \\
\overline{-} \\
42\left(21.5^{\circ} \mathrm{C}\right)\end{array}$ \\
\hline TY-101 & $\begin{array}{l}08 / 04 / 94(2) \\
04 / 06 / 95(3)\end{array}$ & $\begin{array}{l}<1 \\
--\end{array}$ & $\begin{array}{l}4 \\
--\end{array}$ & $\begin{array}{l}12 \\
-\end{array}$ & $\begin{array}{l}16 \\
16\end{array}$ & $\begin{array}{c}<0.01 \\
--\end{array}$ & $\begin{array}{l}<0.2 \\
<0.2\end{array}$ & $\overline{1.0}$ & $<-\bar{c}$ & $\overline{98}$ & $<\overline{12}$ & $\overline{83}$ & $77\left(15.6^{\circ} \mathrm{C}\right)$ \\
\hline TY-103 & $\begin{array}{l}08 / 04 / 94(2) \\
04 / 11 / 95 \text { (3) }\end{array}$ & $\begin{array}{r}<1 \\
--\end{array}$ & $\begin{array}{l}5 \\
--\end{array}$ & $\begin{array}{l}30 \\
-\end{array}$ & $\begin{array}{l}31 \\
49\end{array}$ & $\begin{array}{c}<0.01 \\
-\end{array}$ & $\begin{array}{l}<0.1 \\
<0.2\end{array}$ & $\overline{60}$ & $<\ddot{-}$ & 159 & $<\overline{12}$ & $\overline{121}$ & $85\left(15.9^{\circ} \mathrm{C}\right)$ \\
\hline TY-104 & $\begin{array}{l}08 / 05 / 94 \text { (2) } \\
04 / 27 / 95 \text { (3) }\end{array}$ & $<$ & $\begin{array}{l}2.5 \\
--\end{array}$ & $\begin{array}{c}24 \\
--\end{array}$ & $\begin{array}{l}50 \\
61\end{array}$ & $\overline{-}$ & $\begin{array}{l}<0.2 \\
\leq 0.2\end{array}$ & $\overline{3}$ & $<\overline{-}$ & $\ddot{98}$ & $<\overline{23}$ & $<\overline{23}$ & $88\left(15.6^{\circ} \mathrm{C}\right)$ \\
\hline
\end{tabular}

Sample Type:

**Vapor samples taken from in-tank, non-heated tubes using a vapor sampling cart (SUMMA ${ }^{\mathrm{TM}}$ only - no $\mathrm{NH}_{3}$ ).

1 Monitoring performed by Industrial Hygiene technicians using three varying length, non-heated sampling tubes into the tank headspace to evaluate for flammability and toxic vapors; this method is no longer used.

2 In Situ Sampling (ISS) - Sampling is performed by lowering special sorbent traps into the tank headspace that are connected topside to a portable handcart.

3 Sampling involves the mobile vapor sampling system, heated transfer lines, and installation of a water-heated sampling probe into the tank headspace. All ferrocyanide tanks are scheduled for resampling using this method.

b Measured using a combustible gas meter; LEL = Lower Explosive Limit.

- Measured using an Organic Vapor Monitor (OVM). OVM readings are affected by ammonia; OVM ammonia response is about 13:1, so that 13 ppmv of ammonia is indicated as $1 \mathrm{ppmv}$ of organic vapors (ppmv = parts per million by volume).

- For Type 1 sampling only; value is measured using colorimetric ( $\operatorname{Drager}^{\mathrm{TM}}$ ) tubes (values are estimated, and not quantitative).

- Analyses of ammonia sorbent trap samples.

- Total non-methane organic compound (TNMOC) concentrations measured for SUMMA ${ }^{\text {TM }}$ canister samples.

- Analyses of SUMMA ${ }^{\mathrm{TM}}$ canister samples from Type ${ }^{* *}$, and 3 sampling methods.

h $\%$ RH is the percent relative humidity calculated from measured headspace water content $(\mathrm{mg} / \mathrm{L})$, temperature and atmospheric pressure. Temperature of headspace gas in ${ }^{\circ} \mathrm{C}$ is listed in parentheses.

' HCN determinations obtained in selected tanks using a special sorbent trap; values shown are below detection limit of the measurement technique.

1.- Data not yet available or not obtained by this type of sampling.

- This HCN number was < 0.04 parts per billion vapor as determined by a special sodium hydroxide bubbler. 


\section{APPENDIX REFERENCES}

Borsheim, G. L., and B. C. Simpson, 1991, An Assessment of the Inventories of Ferrocyanide Watch List Tanks, WHC-SD-WM-EP-133, Rev. 0, Westinghouse Hanford Company, Richland, Washington.

Crowe, R. D., M. Kummerer, and A. K. Postma, 1993, Estimation of Heat Load in Waste Tanks Using Average Vapor Space Temperatures, WHC-EP-0709, Rev. 0, Westinghouse Hanford Company, Richland, Washington.

Crowe, R. D., D. P. Maassen, and S. A. Parra, 1995, Calculated Heat Load for Watchlist Single-Shell Waste Tanks Using the Average Vapor Space Temperatures, (letter report attached to internal memorandum from H. Toffer to R. J. Cash, September 29), Westinghouse Hanford Company, Richland, Washington.

Simpson, B. C., G. L. Borsheim, and L. Jensen, 1993a, Tank Characterization Report: Tank 241-C-109, WHC-EP-0688, Westinghouse Hanford Company, Richland, Washington.

Simpson, B. C., G. L. Borsheim, and L. Jensen, 1993b, Tank Characterization Data Report: Tank 241-C-112, WHC-EP-0640, Rev. 1, Westinghouse Hanford Company, Richland, Washington. 


\section{WHC-EP-0474-20}

This page intentionally left blank. 


\section{DISTRIBUTION}

Number of copies

OFFSITE

6

2

1

1

1

1

1
U.S. Department of Energy

EM-38, Trevion II

12800 Middlebrook Road

Germantown, MD 20874

Harry Calley (4)

Maureen Hunemuller

Ken Lang

U.S. Department of Energy

Forrestal Building

1000 Independence Avenue SW

Washington, DC 20585

Shirley Campbell, EH-71

John Kaysak, EM-25

Charles S. Abrams

1987 Virginia

Idaho Falls, ID 83404

David O. Campbell

102 Windham Road

Oak Ridge, TN 37830

Fred N. Carlson

6965 North 5th West

Idaho Falls, ID 83401

Billy C. Hudson

202 Northridge Court

Lindsborg, KA 67456

Thomas S. Kress

102-B Newridge Road

Oak Ridge, TN 37839 


\section{DISTRIBUTION (Continued)}

Number of copies

\section{OFFSITE}

Thomas E. Larson

2711 Walnut Street

Los Alamos, NM 87544

1

Air Products \& Chemicals, Inc. 7201 Hamilton Blvd

Allentown, PA 18195-1501

George E. Schmauch

1

Brookhaven National Laboratory

Upton, NY 11973

Kamal K. Bandyopadhyay

2

Fauske and Associates, Inc. 16W070 W. 83rd St.

Burr Ridge, IL 60521

Michael Epstein

Hans K. Fauske

1

G \& P Consulting Inc. 3640 Ballard Road

Dallas, OR 97338

Arlin K. Postma

1

Harvard University 295 Upland Avenue

Newton Highlands, MA 02161

Melvin W. First 


\section{DISTRIBUTION (Continued)}

\section{Number of copies}

\section{OFFSITE}

1

1

1

1

1
Los Alamos National Laboratory

P.O. Box 1663

Los Alamos, NM 87545

Steve F. Agnew

MIT/Department of Nuclear Engineering

77 Massachusetts Ave.

Room 24-102

Cambridge, MA 02139

Mujid S. Kazimi

Nuclear Consulting Services, Inc.

P.O. Box 29151

Columbus, $\mathrm{OH} \quad 43229-0151$

J. Louis Kovach

Qak Ridge National Laboratory

Emory D. Collins

P.O. Box 2008

7930, MS-6385

Oak Ridge, TN 37831-6385

Charles W. Forsberg

P.O. Box 2008

MS-6495

Oak Ridge, TN 37831-6495

Rice University

5211 Paisley

Houston, TX 77096

Andrew S. Veletsos 


\section{DISTRIBUTION (Continued)}

Number of copies

\section{QFFSITE}

2

1

1

1
Sandia National Laboratories

P.O. Box 5800

Albuquerque, NM 87185

Dana A. Powers, MS-0744

Scott E. Slezak, MS-0741

Science Applications International Corporation 20300 Century Blvd, Suite 200-B

Germantown, MD 20874

Paul Hogroian (3)

State of Washington - Department of Ecology

Robert C. King

P. O. Box 47600

Olympia, WA $98504-7600$

Alex B. Stone

1315 W. 4th Avenue

Kennewick, WA 99336

Waste Policy Institute

555 Quince Orchard Road, Suite 600

Gaitherburg, MD 20878-1437

Donald T. Oakley 
DISTRIBUTION (Continued)

\section{QNSITE}

10

U.S. Department of Energy

Richland Operations Office

W. F. Hendrickson $\quad$ S7-54

D. H. Irby $\quad$ S7-54

M. F. Jarvis (2) S7-54

A. G. Krasopoulos A4-81

J. K. McClusky S7-50

J. C. Peschong S7-53

Public Reading Room H2-53

RL Docket File (2) B1-17

$4 \quad$ Pacific Northwest Laboratory

J. W. Brothers K5-22

R. T. Hallen P8-38

M. A. Lilga P8-38

Hanford Technical Library $\quad$ P8-55

31 Westinghouse Hanford Company

H. Babad $\quad \$ 7-30$

J. B. Billetdeaux $\$ 7-15$

W. S. Callaway $\quad$ S3-90

R. J. Cash (5) S7-14

M. D. Crippen L5-31

R. D. Crowe H0-38

M. L. Dexter R1-51

D. R. Dickinson L5-31

G. T. Dukelow S7-14

S. J. Eberlein R2-12

J. M. Grigsby A3-37

M. N. Islam R3-08

D. W. Jeppson L5-31

N. W. Kirch R2-11

C. A. Kuhlman B3-30

L. L. Lockrem $\quad$ S3-90 


\section{DISTRIBUTION (Continued)}

Westinghouse Hanford Comoany (Continued)

J. E. Meacham (2)

S7-14

N. J. Milliken

H4-65

S. R. Moreno

B3-06

F. R. Reich

L5-55

E. F. Riedel

S3-90

B. C. Simpson

R2-12

Central Files

A3-88

Correspondence Processing

A3-01

EDMC

H6-08

DPC

A3-94 